V.M. Gun'ko

\title{
VARIOUS METHODS TO DESCRIBE THE MORPHOLOGICAL AND TEXTURAL CHARACTERISTICS OF VARIOUS MATERIALS
}

\author{
Chuiko Institute of Surface Chemistry of National Academy of Sciences of Ukraine \\ 17 General Naumov Str., Kyiv, 03164, Ukraine, E-mail: vlad gunko@ukr.net
}

The aim of this study was to compare a variety of methods to describe the textural characteristics of various materials. Several ways could be used to describe the morphological and textural characteristics of various materials in detail such as: (i) adsorption-desorption of low-molecular weight probe compounds $\left(\mathrm{N}_{2}, \mathrm{CO}_{2}, \mathrm{Ar}, \mathrm{C}_{6} \mathrm{H}_{6}\right.$, $\mathrm{H}_{2} \mathrm{O}$, etc.) in the gaseous (vapor) phase with increasing-decreasing pressure; (ii) adsorption of low-or highmolecular weight compounds from liquid solutions with increasing concentration of a solute; (iii) small angle X-ray scattering (SAXS) or small angle neutron scattering (SANS); (iv) quantitative analysis of images recorded using TEM, SEM, AFM, CLSM, etc.; (v) thermoporometry based on DSC or TG measurements with decreasing-increasing temperature; (vi) cryoporometry based on NMR spectroscopy measurements vs. temperature; and (vii) relaxometry based on NMR spectroscopy and thermally stimulated depolarization current measurements. There are several reasons of the use of mentioned above methods in parallel. For example, a material, which is strongly hydrated in native state, can strongly change the texture upon drying; thus, it should be studied in both states. Various adsorbates can penetrate into different pores or differently fill pores of different sizes that should be taken into account upon the analyses of various data. There are accessible and inaccessible pores (such as closed or too narrow for used adsorbate molecules), but SAXS can give information on all pores in contrast to the adsorption methods. Thus, the larger the number of applied methods, the more comprehensive the morphological and textural characterization of the adsorbents, and this is clearly shown below.

Keywords: textural characteristics, adsorption, cryoporometry, relaxometry, thermoporometry, SAXS, FTIR

\section{INTRODUCTION}

Dispersion media, temperature, pressure, treatment history, and some other conditions can strongly affect the morphological, textural, and other characteristics of materials those, of course, depend on composition and chemical structure of the materials per se [1-12]. Material application conditions can strongly differ from conditions during measurements of their characteristics that can result in the evaluation errors with respect to expected results of the applications. Clear, a measurement of a certain characteristic should be carried out under conditions similar to those expected upon the use of a material. Therefore, various techniques should be used upon measurements of the characteristics of various materials under various conditions for a deeper insight into the characterization problems and to understand related features of the materials studied. Additionally, it is better if the measurements are carried out under varied conditions to analyze their effects on the characteristics of the materials (which are dried - wetted, heated cooled, being under high pressure - air - vacuum, etc.), their stability and durability [9-23]. The aim of this review work was to show representative results of applications of different methods (Fig. 1), including specific treatments of the data, to a variety of materials for more comprehensive description of the morphological and textural characteristics.

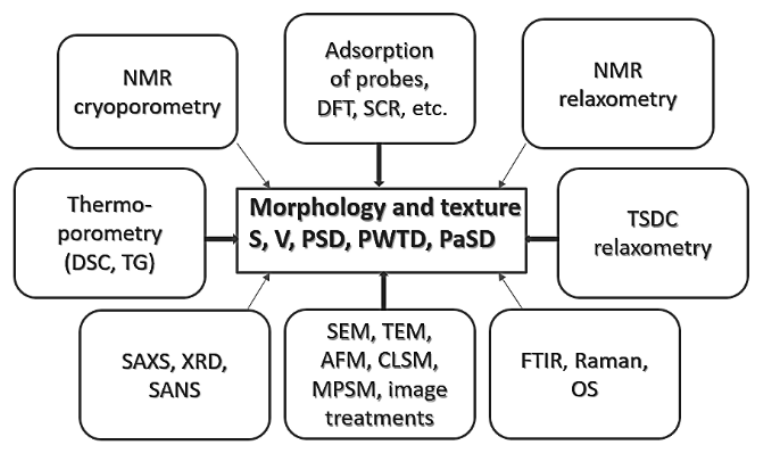

Fig. 1. A set of methods applied to a set of materials to determine the morphological and textural characteristics 
The main idea of this work could be formulated as follows: the larger the number of applied methods, the more comprehensive the morphological and textural characterization of the adsorbents. Some of the used methods are described here in detail, but others are described in detail in the cited literature.

\section{CHARACTERIZATION METHODS}

Adsorption. To calculate the textural characteristics of complex materials, the nitrogen adsorption-desorption isotherms (recorded at $77.4 \mathrm{~K}$ using Micromeritics ASAP 2010 or $2405 \mathrm{~N}$ adsorption analyzers) could be written as a sum of integral equations [12]

$$
\begin{aligned}
& a_{\Sigma}(p)=\sum_{j} c_{j} a_{j}(p)= \\
& =\sum_{j} c_{j}\left[\int_{r_{\text {min }}}^{r_{k, j}(p)} f_{V, j}\left(R_{p}\right) d R_{p}+\int_{r_{k, j}(p)}^{r_{\text {max }}} \frac{w_{j}}{R_{p}-\sigma_{s f} / 2} t_{j}\left(p, R_{p}\right) f_{V, j}\left(R_{p}\right) d R_{p}\right]
\end{aligned}
$$

where $a_{\Sigma}$ and $a_{j}$ are the total adsorption and adsorption in pores of a certain shape; $\sigma_{\mathrm{sf}}=$ $=\left(\sigma_{\mathrm{s}}+\sigma_{\mathrm{f}}\right) / 2$ is the average collision diameter of surface and fluid atoms; $r_{k, j}$ is determined through modified Kelvin equation including the thickness of the adsorbate layer $t_{j}$. The LennardJones potentials were used for various models of pores. The $c_{\mathrm{j}}$ values were determined for the best fitting of the experimental isotherms using a selfconsistent regularization (SCR) procedure with several steps in solution of Eq. (1). The nitrogen desorption data could be used to compute the pore size distributions (PSD, differential $f_{\mathrm{V}}(R) \sim$ $\mathrm{d} V_{\mathrm{p}} / \mathrm{d} R$ and $\left.f_{\mathrm{S}}(R) \sim \mathrm{d} S / \mathrm{d} R\right)$ using the SCR procedure under non-negativity condition $\left(f_{\mathrm{V}}(R) \geq 0\right.$ at any pore radius $\left.R\right)$ at a fixed regularization parameter $\alpha=0.01$. A complex pore model was applied with slit-shaped $(S)$ and cylindrical $(C)$ pores and voids $(V)$ between spherical nonporous nanoparticles (NPNP) packed in random aggregates (SCV/SCR method) [12]. The differential PSD with respect to the pore volume $f_{\mathrm{V}}(R) \sim \mathrm{d} V / \mathrm{d} R, \int f_{\mathrm{V}}(R) \mathrm{d} R \sim V_{\mathrm{p}}$ were recalculated to incremental PSD (IPSD) at $\Phi_{\mathrm{V}}\left(R_{i}\right)=\left(f_{\mathrm{V}}\left(R_{i+1}\right)+f_{\mathrm{V}}\left(R_{i}\right)\right)\left(R_{\mathrm{i}+1}-R_{\mathrm{i}}\right) / 2$ at $\sum \Phi_{\mathrm{V}}\left(R_{i}\right)$ $\left.=V_{\mathrm{p}}\right)$. The $f_{\mathrm{V}}(R)$ and $f_{\mathrm{S}}(R)$ functions were also used to calculate contributions of nanopores ( $V_{\text {nano }}$ and $S_{\text {nano }}$ at $0.35 \mathrm{~nm}<R<1 \mathrm{~nm}$ ), mesopores ( $V_{\text {meso }}$ and $S_{\text {meso }}$ at $1 \mathrm{~nm}<R<25 \mathrm{~nm}$ ), and macropores ( $V_{\text {macro }}$ and $S_{\text {macro }}$ at $25 \mathrm{~nm}<R<100 \mathrm{~nm}$ ) [12]. To describe better the porosity of the studied samples, an additional regularizer was derived using a maximum entropy principle [24] applied to the distribution function $f(R)$ that can be written as $N$-dimension $\operatorname{vector}(N$ is the number of the grid points for $f$ )

$V A R+\alpha^{2}\left(1-\frac{S(\vec{p}(\vec{f}))}{S_{\max }}\right) \rightarrow \min$,

where $V A R$ is the regularizer, $\alpha$ is the regularization parameter, $\quad \vec{p}^{0}(\vec{f})=\vec{f}$, $p_{i}^{1}(\vec{f})=f_{i+1}-f_{i}+\left(f_{\max }-f_{\min }\right) ; i=1, \ldots N-1$, $p_{i}^{2}(\bar{f})=f_{i+1}-2 f_{i}+f_{i-1}+2\left(f_{\max }-f_{\min }\right), i=$ $2, \ldots N-1, \quad S(\vec{f})=-\sum_{k=1}^{N} s_{k} \ln \left(s_{k}\right), \quad s_{k}=f_{k} / \sum_{k=1}^{N} f_{k}$, $S_{\max }=-\ln \left(\frac{1}{N}\right)$.

The $\vec{p}^{j}(\vec{f})$ vector corresponds to the maximum entropy principle of the $j$-order. This procedure was used to modify the CONTIN algorithm [25,26] (CONTIN/MEM-j where $j$ denotes the order of $\left.\vec{p}^{j}(\vec{f})\right)$. A self-consistent regularization procedure with an unfixed regularization parameter (for better fitting the isotherms) was used upon CONTIN/MEM- $j$ calculations.

The specific surface area $\left(S_{\varphi}\right)$ of materials composed of spherical NPNP characterized by the particle size distribution $\varphi(a)$ (calculated using the self-consistent regularization for $f_{\mathrm{V}}(R)$ and $\varphi(a)$ with the model of voids between spherical NPNP) can be calculated with equation

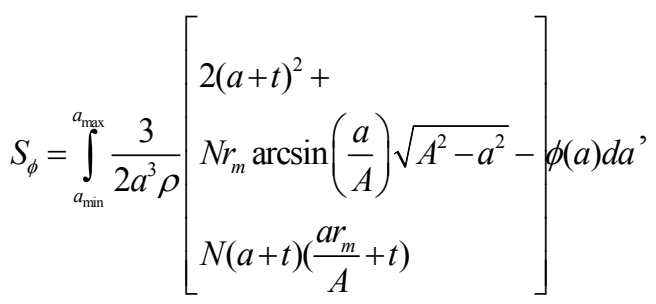

where $A=a+t+r_{m}, a$ is the particle radius, $\rho$ the density of material, $N$ the average coordination number of nanoparticles in aggregates, $t$ the thickness of an adsorbed nitrogen layer, and $r_{\mathrm{m}}$ is the meniscus radius determined at $0.05<p / p_{0}<0.2$ corresponding to the effective radius $R$ of voids between spherical particles. Condition $S_{\varphi}=S_{\mathrm{BET}}$ can be used to 
estimate the $N$ value. An additional criterion $\left|<S_{\varphi}>-S_{\mathrm{BET}}\right|<1 \mathrm{~m}^{2} / \mathrm{g}$ was used to determine the $a_{\min }$ and $a_{\max }$ values for the $\varphi(a)$ distributions calculated at $p / p_{0}<0.5$ (i.e. before capillary condensation starts) with

$$
<S_{\phi}>=\iint S_{\phi}\left(r_{m}, t\right) d t d r_{m} / \iint d t d r_{m} .
$$

Certain PSD were calculated using nonlocal density functional theory (NLDFT) method (with the models of slit-shaper, silt-shaped/cylindrical or cylindrical pores in carbons or silicas) and quenched solid DFT (QSDFT) method (a slitshaped pore model for carbons) (Quantachrome software, version 2.02 or 3.0).

$\boldsymbol{S A X S}$. The pore size distributions $f(r)$ based on the small angle X-ray scattering (SAXS) data were calculated using integral equation for the scattering intensity $I(q)$ [19] that was solved using the CONTIN algorithm [25]

$$
I(q)=C \int_{R_{\min }}^{R_{\max }} \frac{(\sin q r-q r \cos q r)^{2}}{(q r)^{2}} v(r) f(r) d r,
$$

where $q=4 \pi \sin (\theta) / \lambda$ is the scattering vector value, $2 \theta$ is the scattering angle, $\lambda$ is the wavelength of incident X-ray, $v(r)$ is the volume of a pore with radius $r$ (proportional to $r^{3}$ ), and $f(r) \mathrm{d} r$ represents the probability of having pores with radius $r$ to $r+d r . \quad R_{\min }\left(=\pi / q_{\max }\right)$ and $R_{\max }\left(=\pi / q_{\min }\right)$ correspond to lower and upper limit of the resolvable real space due to instrument resolution.

The chord size distribution $G(r)$, as a geometrical statistic description of a multiphase medium, was calculated using SAXS data $[3,20]$

$$
G(r)=C \int_{0}^{\infty}\left[K-q^{4} I(q)\right] \frac{d^{2}}{d r^{2}}\left(-4 \frac{\sin q r}{q r}\right) d q,
$$

where $K$ is the Porod constant (scattering intensity $I(q) \sim \mathrm{Kq}^{-4}$ in the Porod range).

The specific surface area from the SAXS data was calculated (in $\mathrm{m}^{2} / \mathrm{g}$ ) using equation

$S_{\mathrm{SAXS}}=10^{4} \pi \phi(1-\phi) \frac{K}{Q \rho_{a}}$,

where $\phi=\rho_{a} / \rho_{0}$ is the solid fraction of adsorbent, and $Q$ is the invariant
$Q=\int_{0}^{\infty} q^{2} I(q) d q$

The $Q$ value is sensitive to the range used on integration of Eq. (8) (since the experimental $q$ values are measured between the $q_{\min }$ and $q_{\max }$ values different from 0 and $\infty$ ). Therefore, the invariant value $Q$ was calculated using equation [21]

$Q=\sum_{q_{\min }}^{q_{\max }}\left(I\left(q_{i}\right)-b\right) q_{i}^{2} \Delta q_{i}+K / q_{\max }$

where $b$ is a constant determined using equation

$I(q) q^{4}=K+b q^{4}$

valid in the Porod range.

The particle size distributions (PaSD) for nanosilica A-300 samples were calculated using PAN analytical Easy SAXS V. 2.0.0.405 program. The SAXS based approach was successfully applied to carbon, silica, and polymeric materials in comparison with the results of different methods used to analyze the nitrogen adsorption data [14, 27, 28].

${ }^{1} \boldsymbol{H}$ NMR cryoporometry. Water or other liquids can be frozen in narrower pores (or voids between nanoparticles) at lower temperatures as described by the Gibbs-Thomson relation for the freezing (and melting) point $\left(T_{\mathrm{f}}\right.$ or $\left.T_{\mathrm{m}}\right)$ depression for liquids confined in cylindrical pores of radius $R[9-11,22,23]$

$\Delta T_{m}=T_{m, \infty}-T_{m}(R)=-\frac{2 \sigma_{s l} T_{m, \infty}}{\Delta H_{f} \rho R}=\frac{k_{G T}}{R}$,

where $T_{\mathrm{m}}(R)$ is the melting temperature of ice (or other frozen probes) in cylindrical pores of radius $R, T_{\mathrm{m}, \infty}$ the bulk melting temperature, $\Delta H_{\mathrm{f}}$ the bulk enthalpy of fusion, $\rho$ the density of the solid, $\sigma_{\mathrm{sl}}$ the energy of solid-liquid interaction, and $k_{\mathrm{GT}}$ is the Gibbs-Thomson constant. Eq. (11) was used to determine the cluster size distributions $(\mathrm{CSD}) \quad\left(f_{\mathrm{v}}(R)=d V_{\mathrm{uw}}(R) / d R\right) \quad$ of water (or other liquids at $T<T_{\mathrm{f}}$ ) unfrozen at $T<273 \mathrm{~K}$ [11] and adsorbed onto solid samples. CSD was converted into incremental CSD $(\mathrm{ICSD}) \Phi_{\mathrm{V}}\left(R_{i}\right)=\left(f_{\mathrm{V}}\left(R_{i+1}\right)+f_{\mathrm{V}}\left(R_{i}\right)\right)\left(R_{\mathrm{i}+1}-R_{\mathrm{i}}\right) / 2$ at $\sum \Phi_{\mathrm{V}, \mathrm{i}}(R)=V_{\mathrm{uw}}$. Integration of the $f_{\mathrm{V}}(R)$ and $f_{\mathrm{S}}(R)$ functions at $R<1 \mathrm{~nm}, 1 \mathrm{~nm}<R<25 \mathrm{~nm}$, and $25 \mathrm{~nm}<R<100 \mathrm{~nm}$ gives the volume and specific surface area of nano-, meso- and 
macropores, respectively. The specific surface area $\left(S_{\mathrm{u}}\right)$ of adsorbents in contact with bound water (assuming for simplicity that the density of unfrozen bound water $\rho_{\mathrm{uw}}=1 \mathrm{~g} / \mathrm{cm}^{3}$ ) or other unfrozen liquids can be determined from the amount of this water $C_{u w}^{\max }$ (estimating pore volume as $V_{\mathrm{uw}}=C_{u w}^{\max } / \rho_{\mathrm{uw}}$ for bound water) at $T=273.15 \mathrm{~K}$ and pore size distribution $f(R)$ with a model of cylindrical pores [11]

$$
S_{u w}=\frac{V_{u w}}{2 R_{a v}}=\frac{2 C_{u w}^{\max }}{\rho_{u w}} \int_{R_{\min }}^{R_{\max }} f(R) d R / \int_{R_{\min }}^{R_{\max }} f(R) R d R,
$$

where $R_{\min }$ and $R_{\max }$ are the minimal and maximal radii of pores filled by unfrozen water, respectively. The $C_{u w}^{\max } / \rho_{u w}$ value should be replaced by the corresponding values of the volumes of nanopores, mesopores, or macropores. Similar calculation could be done for other probe liquids at $T<T_{\mathrm{m}}$.

NMR relaxometry. The transverse relaxation times were measured with Carr-PurcellMeiboom-Gill (CPMG) pulse sequence: $90 x-(\tau-$ $180 y-\tau$-echo $)_{n}$ with $90^{\circ}$ pulse of $3 \mu$ s and total echo time of $500 \mu \mathrm{s}$. A total of eight scans were used for each measurement. The relaxation time between scans was $0.5 \mathrm{~s}$. Equilibration time of each temperature was $5 \mathrm{~min}$. To calculate a distribution function of transverse relaxation time $f(T 2)$, CPMG echo decay envelopes $(I(t))$ were used as the left term of integral equation

$$
I(t)=A \int_{T 2_{\min }}^{T 2_{\max }} \exp \left(-\frac{t}{T 2}\right) f(T 2) d T 2,
$$

where $t$ is the time, $T 2_{\min }$ and $T 2_{\max }$ are the minimal $\left(10^{-6} \mathrm{~s}\right)$ and maximal $(1 \mathrm{~s}) T 2$ values on integration respectively, and $A$ is a constant. Solution of Eq. (13) is well known ill-posed problem due to the impact of noise on measured data, which does not allow one to utilize exact inversion formulas or iterative algorithms. Therefore, Eq. (13) can be solved using a regularization procedure based on the CONTIN algorithm [25] under nonnegativity condition $(f(T 2) \geq 0$ at any $T 2)$ and an unfixed value of the regularization parameter $(\alpha)$ determined on the basis of the F-test and confidence regions using the parsimony principle. It should be noted that the solution of Eq. (13) is insensitive to the $A$ value which can affect only relative intensity of
$f(T 2)$ [26]. In the case of the use of the NMR relaxometry method for estimation of the sizes of the water and benzene structures (layers, clusters, etc.) filling pores, equation can be transformed for consideration for the dependence of the CPMG echo decay envelopes (i.e. transverse relaxation time) on the pore size

$I_{i}(t)=B \int_{R_{\min }}^{R_{\max }} \exp \left(-\frac{t}{T 2_{i, m}}\right) \frac{\left(T_{m, \infty, i}-T_{m, i}(R)\right)}{k_{i}} f_{i}(R) d R$,

where $B$ is a normalization factor, and $k_{i}$ is a constant. Eq. (14) can be solved using the regularization procedure $[25,26]$.

TSDC relaxometry. On thermally stimulated depolarization current (TSDC) measurements, the tablets (diameter $30 \mathrm{~mm}$, thickness $\sim 1 \mathrm{~mm}$ ) with the frozen aqueous suspension of materials studied were polarized by the electrostatic field at the intensity $F_{\mathrm{p}}=200-300 \mathrm{kV} / \mathrm{m}$ at $260 \mathrm{~K}$ then cooled to $90 \mathrm{~K}$ with the field still applied and heated without the field at the heating rate $\beta=0.05 \mathrm{~K} / \mathrm{s}$. The current evolving due to sample depolarization [29] was recorded by an electrometer over the $10^{-15}-10^{-7}$ A range. Relative mean errors for measured TSD current were $\delta_{I}= \pm 5 \%, \delta_{T}= \pm 2 \mathrm{~K}$ for temperature, $\delta_{\beta}= \pm 5 \%$ for the temperature change rate.

$C_{u, i}(T)=A \int_{R_{\min }}^{R_{\max }}\left(\frac{k_{i}}{\left(T_{m, \infty, i}-T_{m, i}(R)\right) R}\right)^{2} f_{i}(R) d R$.

Modified Eq. (15) with $k$ as a linear function of temperature $\left(k(T)=40+\frac{5}{6}(T-90) \mathrm{K} \mathrm{nm}\right.$ at $T$ between 90 and $270 \mathrm{~K}$ ) obtained on the basis of the calibration curves for silica gels $\mathrm{Si}-40$ and Si-60 was used for estimations of the IPSDs on the basis of the TSDC data [11, 29, 30].

DSC thermoporometry. Differential scanning calorimetry (DSC) investigations of interactions of adsorbents with nonpolar (e.g. benzene, toluene, $n$-decane), weakly polar (chloroform), and polar (water, acetonitrile, DMSO, etc.) adsorbates were carried out using a PYRIS Diamond (Perkin Elmer Instruments, USA) differential scanning calorimeter calibrated at different heating rates using standard samples such as ultrapure water (melting temperature $T_{\mathrm{m}}=0{ }^{\circ} \mathrm{C}$ ) and indium $\left(T_{\mathrm{m}}=156.6^{\circ} \mathrm{C}\right)$ supplied by the producer and using the recommended standard calibration procedure. Measurements were carried out in an 
atmosphere of inert gas (helium). In order to prevent the system defrosting, nitrogen was used as a curtain gas. Experiments were performed at a rate of temperature change in the range of $5-50{ }^{\circ} \mathrm{C} \cdot \mathrm{min}^{-1}$. Heating thermograms were registered in the temperature range of -90 to $+50{ }^{\circ} \mathrm{C}$.

Melting DSC curves of bound water (ice) [31-34] can be used to calculate the pore sizes as follows:

$$
R_{p}(n m)=0.68-\frac{32.33}{T_{m}-T_{m 0}},
$$

where $T_{\mathrm{m}}$ and $T_{\mathrm{m} 0}$ are the melting temperatures of confined and bulk water, respectively. The pore size distribution $d V / d R$ can be calculated from the DSC melting curves of bound ice

$$
\frac{d V}{d R}\left(\mathrm{~cm}^{3} n m^{-1} \mathrm{~g}^{-1}\right)=\frac{\frac{d q}{d t}\left(T_{m}-T_{m 0}\right)^{2}}{32.33 \rho \beta m \Delta H(T)},
$$

where $d q / d t, \rho, \beta, m$ and $\Delta H(T)$ are the DSC heat flow, the water density, the heating rate, the sample mass and the melting enthalpy of ice, respectively. The differences in the PSD of silicas and the adsorbate excess lead to certain changes in integral heat flow $(\Phi(T))[35]$

$\Phi(T)=\int_{T_{\min }}^{T}|F(T)| d T$,

during heating (endo-effects due to melting) of adsorbates bound to adsorbents.

\section{Thermogravimetry - thermoporometry.}

Thermogravimetric (TG) experiments were carried out using a Derivatograph C (MOM, Hungary) apparatus with the quasi-isothermal program at a heating rate of $3 \mathrm{~K} / \mathrm{min}$ (upon complete evaporation of adsorbates). To remove adsorbed water, the samples were heated before experiment at $180{ }^{\circ} \mathrm{C}$ in vacuum for several hours. Prior to experiment, silica gels were outgassed to facilitate the penetration of liquid adsorbate into pores in gel-like paste prepared with excess of adsorbate (up to $2.66 \mathrm{ml}$ per gram of silica). The samples were placed in a conical platinum crucible. For easy comparison of the TG results, the curves were normalized by subtraction of the silica weight and dividing by the initial weight of a liquid. Thermoporometry method $[16,36,37]$ was used to calculate the
PSD based on the water desorption vs. temperature.

Infrared spectroscopy. The IR spectra of powdered samples over the $4000-300 \mathrm{~cm}^{-1}$ range (at $4 \mathrm{~cm}^{-1}$ resolution) were recorded in transmission mode using a Specord M80 (Carl Zeiss, Jena) spectrometer using sample powders mixed with $\mathrm{KBr}(1: 400)$, treated in a microbreaker (with a stainless steel sphere of $10 \mathrm{~cm}^{3}$ in volume and a stainless steel ball of $0.8 \mathrm{~cm}$ in diameter, $30 \mathrm{~W}$, and frequency $50 \mathrm{~Hz}$ ) for $5 \mathrm{~min}$ to prepare a uniform blend, and then pressed at $99 \mathrm{MPa}$ to form thin tablets $(\sim 20 \mathrm{mg})$ [18]. This provides a transmittance of $>10 \%$ in the range of the $\mathrm{Si}-\mathrm{O}-\mathrm{Si}$ asymmetric stretching vibrations at $1100 \mathrm{~cm}^{-1}$ for silica. The transmittance spectra were recalculated into absorbance spectra. For simplicity, the complex band at $1100 \mathrm{~cm}^{-1}$ was decomposed into two bands at $1100 \mathrm{~cm}^{-1}$ (transverse optical, TO, phonon mode, $w_{1}$ ) and $1200 \mathrm{~cm}^{-1}$ (longitudinal optical, LO, phonon mode, $w_{2}$ ) [18]. Both bands shift toward larger values of $v_{\mathrm{SiOSi}}$ with increasing average size (d) of primary nanoparticles of silica. The contribution $\left(w_{2}\right)$ of the second band at $1200 \mathrm{~cm}^{-1}$ decreases with increasing value of $d$. For oxidized silicon nanoparticles, a feature attributed to a surface optical (SO) phonon mode is located between the LO and TO phonon modes. The intensity of LO was higher than that of TO phonon mode.

Basing on the relationship between the values of $w_{2}$ or $w_{2} / w_{1}$ and NP diameter $(d)$, one could attribute the dependence of $w_{2}$ (or $w_{2} / w_{1}$ ) $v s$. $d$ of silica nanoparticles to surface structural features [18]. This dependence could be used to analyze the structure of individual and complex FMO. A polynomic function describing $d$ value $s$. relative contribution $\left(w_{2}, \%\right)$ of the second band around $1200 \mathrm{~cm}^{-1}$ was determined using the correlation curve and provided as Eq. (19) [18]:

$d=2604.06-343.7 w_{2}-13.11\left(w_{2}\right)^{2}+4.75\left(w_{2}\right)^{3}-$ $-32.76 \times 10^{-2}\left(w_{2}\right)^{4}+9.59 \times 10^{-3}\left(w_{2}\right)^{5}-$

$-1.05 \times 10^{-4}\left(w_{2}\right)^{6}$

The relationship between the diameter of nanoparticles of silica and the ratio of $x=w_{2} / w_{1}$ is given as Eq. (20) [18]:

$d=2831.27-53317.04 x+(0.3853-1.235 x+$

$\left.+1.185 x^{2}+2.147 x^{3}-4.064 x^{4}\right) x^{2} \times 10^{6}$ 
Correction of surface content of silica in a complex FMO, estimated from $w_{2}$ values, was calculated using the values of the average diameters of nanoparticles from nitrogen adsorption $\left(d_{\mathrm{N} 2}\right)$ and IR $\left(d_{\mathrm{IR}}\right)$ data (from Eq. (19)) with a factor of $\left(d_{\mathrm{IR}}-d_{\mathrm{N} 2}\right) / d_{\mathrm{IR}}[18]$.

\section{RESULTS AND DISCUSSION}

Mesoporous silicas such as MCM or SBA have more ordered location of pores in comparison with fumed silicas, silica gels, etc. (note that all these adsorbents are composed of amorphous silica as a matter) that is clearly visible from XRD patterns for mesoporous silicas MCM-41 (observed reflections suggest that it can be assigned to 2D hexagonal location of pores with amorphous silica in pore walls), SBA-15 (hexagonal location of pores), and MCM-48 (3D cubic structure) [26]. For hexagonal structure the lattice constant $a_{0}=\frac{2 d_{100}}{\sqrt{3}}$ corresponding to the distance between pore centers, the pore size $d_{X R D}=1.213 d_{100} \sqrt{\frac{\rho_{0} V_{p}}{1+\rho_{0} V_{p}}}\left(\rho_{0}=2.2 \mathrm{~g} / \mathrm{cm}^{3}\right.$ is the true density of amorphous silica) and the pore wall thickness $t_{\text {wall }}=a_{0}-d_{\text {XRD }}$ can be estimated from the $d_{100}$ spacing value. The $d_{X R D}$ and $t_{\text {wall }}$ values for MCM-48 (Table 1) were calculated using the $d_{211}$ spacing value [26].

The average pore wall thickness is between two $(0.62 \mathrm{~nm})$ and four $(1.24 \mathrm{~nm})$ silica layers for the studied samples (Table $1, t_{\text {wall }}$ ). The pore sizes estimated from the XRD (Table $1, d_{\mathrm{XRD}}$ ) and adsorption data $\left(d_{\mathrm{N} 2}\right.$ and $\left.d_{\mathrm{PSD}}\right)$ are similar (with one exception of SBA-15). A significant difference between the $d_{\mathrm{N} 2}$ and $d_{\mathrm{XRD}}$ values for SBA-15 is due to contribution of narrow mesopores at $1<R<2 \mathrm{~nm}$ (Fig. 2) (these pores can be attributed to inner-wall pores), which are out of the main mesopore peak, on calculation of $d_{\mathrm{N} 2}$. The $d_{\mathrm{PSD}}$ value for the main mesopore peak for SBA-15 is closer to $d_{\mathrm{XRD}}$ than $d_{\mathrm{N} 2}$.

Calculation of the $d_{\mathrm{N} 2}$ value only for this peak gives $9.92 \mathrm{~nm}$, which is closer to the $d_{\mathrm{XRD}}$ value. Consequently, on the calculation of the size of the main mesopores from the adsorption data, not only external surface and the corresponding pore volume but also the surface and volume of narrow pores should be taken into account. Notice that a certain difference between the pore sizes determined from the XRD and adsorption data can be caused by neglect or accounting of the size of surface atoms.

The PSD calculated using CONTIN/MEM-0 with a model of cylindrical pores are narrower than those calculated using simple regularization procedure CONTIN (C/SCR model) (Fig. 2). This result could be important on a study of small changes in the PSD during partial modification of a silica surface.
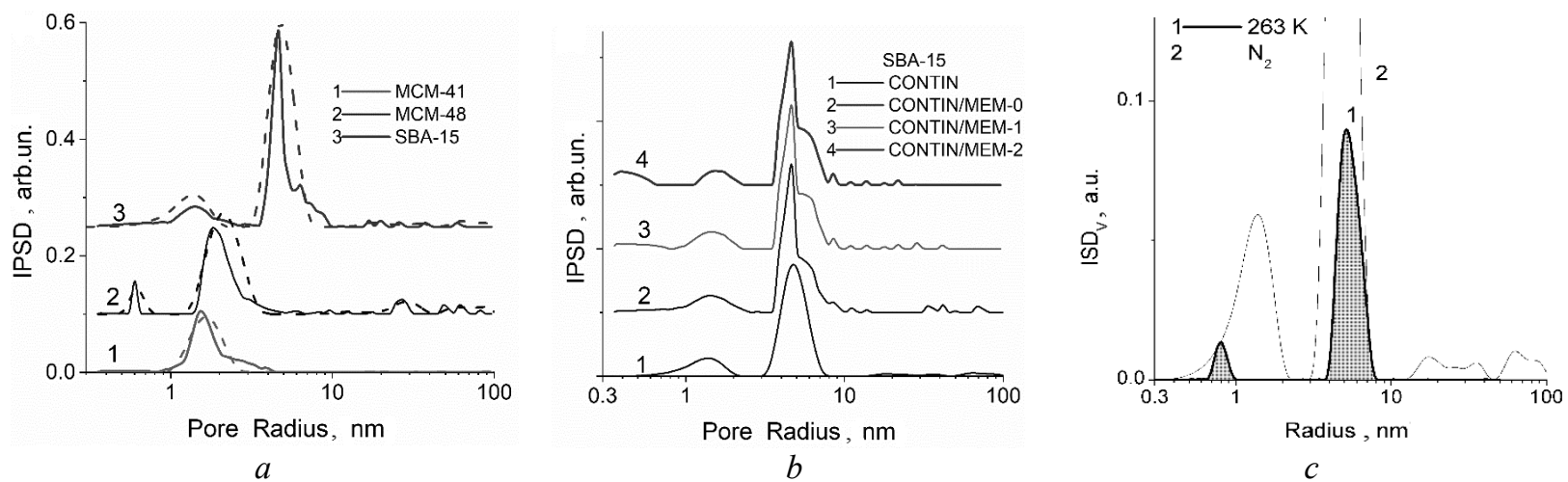

Fig. 2. Incremental pore size distributions of mesoporous silicas using a model of cylindrical pores with (a) CONTIN/MEM-0 (solid line) and CONTIN (dashed line) and (b) SBA-15 with CONTIN and CONTIN/MEM-j, (c) liquid structures calculated on the basis of CPMG echo decay envelopes for benzene adsorbed onto SBA-15 (curve 1) and IPSD based on the nitrogen adsorption data (curve 2) [26] 


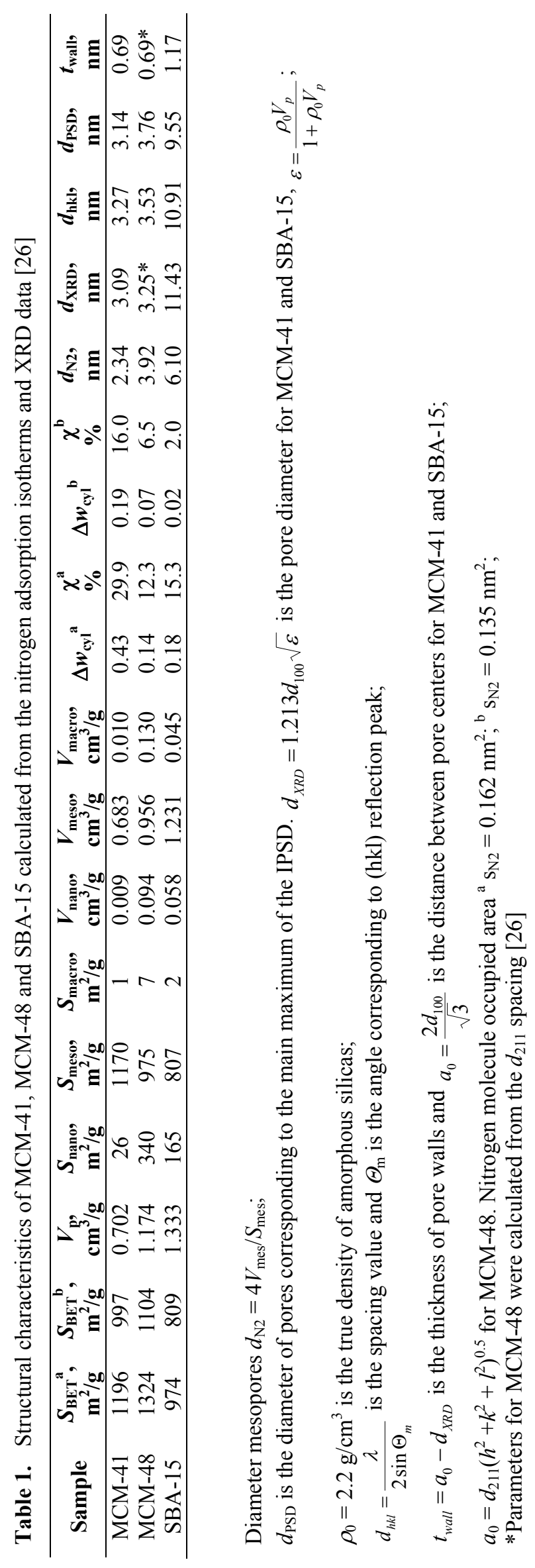


NMR relaxometry gives the PSD with peak position corresponding to that calculated using C/SCR method (Fig. 2 c). Thus, the XRD (as well NMR relaxometry) method could be effectively used for adsorbents with an ordered structure of pores despite amorphous structure of the matter.

One could assume that the small angle X-ray scattering (SAXS) method could give the most correct PSD (Fig. 3) for any material. However, the SAXS method gives the PSD both for open (accessible for probes) and closed (inaccessible for any probes) pores. Therefore, for evaluation of the PSD with respect to the accessibility of different pores for different adsorbates, various methods could be used to calculate the PSD. Note that the PSD calculated on the basis of nitrogen adsorption data using the DFT method [14] gives the PSD similar to the SAXS PSD over a broad range of pore sizes (Fig. 3, curves 5 and 1 , respectively) in contrast to other methods of the adsorption data analyses (vide infra).

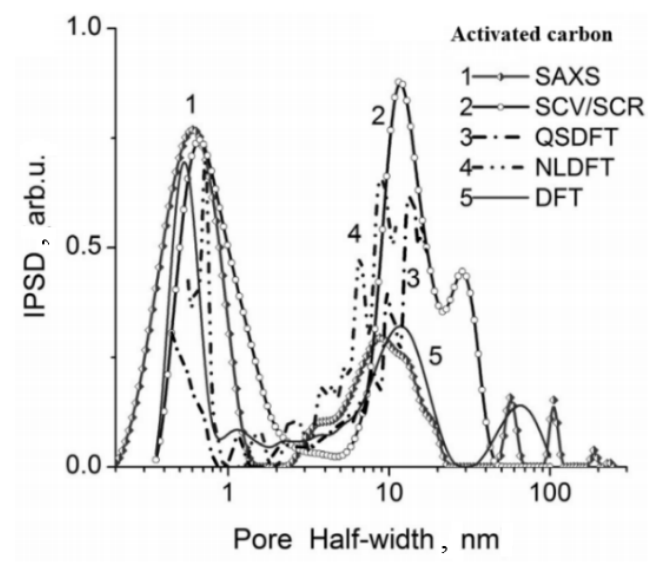

Fig. 3. Pore size distributions for activated carbon (45\% burn-off, $\quad S_{\mathrm{BET}}=1351 \mathrm{~m}^{2} / \mathrm{g}$, $V_{\mathrm{p}}=1.44 \mathrm{~cm}^{3} / \mathrm{g}$ ) calculated using SAXS and nitrogen adsorption methods $[11,14,38,39]$

Table 2. Structural characteristics of activated carbons (model of slit-like pores) activated by $\mathrm{CO}_{2}(\mathrm{C}-\mathrm{x}$ samples) and water vapor (Wf-x and $\mathrm{W}-i$ samples) [39]

\begin{tabular}{lccccccccc}
\hline Sample & $\begin{array}{c}\boldsymbol{S}_{\text {BET }} \\
\mathbf{m}^{\mathbf{2}} / \mathbf{g}\end{array}$ & $\begin{array}{c}\boldsymbol{S}_{\text {nano }} \\
\mathbf{m}^{\mathbf{2}} / \mathbf{g}\end{array}$ & $\begin{array}{c}\boldsymbol{S}_{\mathbf{m e s o}} \\
\mathbf{m}^{\mathbf{2}} / \mathbf{g}\end{array}$ & $\begin{array}{c}\boldsymbol{S}_{\text {macro }} \\
\mathbf{m}^{\mathbf{2}} / \mathbf{g}\end{array}$ & $\begin{array}{c}\boldsymbol{V}_{\mathbf{p}} \\
\mathbf{c m}^{\mathbf{3}} / \mathbf{g}\end{array}$ & $\begin{array}{c}\boldsymbol{V}_{\text {nano }} \\
\mathbf{c m}^{\mathbf{3}} / \mathbf{g}\end{array}$ & $\begin{array}{c}\boldsymbol{V}_{\text {meso }} \\
\mathbf{c m}^{3} / \mathbf{g}\end{array}$ & $\begin{array}{c}\boldsymbol{V}_{\text {macro }} \\
\mathbf{c m}^{3} / \mathbf{g}\end{array}$ & $\Delta \boldsymbol{w}$ \\
\hline C-0 & 549 & 493 & 45 & 11 & 0.981 & 0.259 & 0.253 & 0.469 & 0.007 \\
C-25 & 1082 & 1011 & 65 & 6 & 1.011 & 0.511 & 0.314 & 0.187 & 0.061 \\
C-45 & 1615 & 1510 & 101 & 4 & 1.319 & 0.751 & 0.406 & 0.162 & 0.132 \\
C-62 & 2270 & 2090 & 175 & 4 & 1.683 & 1.004 & 0.505 & 0.175 & 0.240 \\
C-75 & 3047 & 2626 & 413 & 6 & 2.349 & 1.223 & 0.904 & 0.222 & 0.334 \\
C-86 & 3463 & 2181 & 1279 & 3 & 2.320 & 1.314 & 0.887 & 0.119 & 0.304 \\
C-86* & 3463 & 1490 & 1969 & 4 & 2.320 & 0.606 & 1.567 & 0.148 & 0.626 \\
C-30 & 1145 & 1052 & 88 & 5 & 1.187 & 0.554 & 0.469 & 0.164 & 0.157 \\
C-60 & 1999 & 1729 & 250 & 19 & 1.969 & 0.663 & 0.638 & 0.669 & 0.561 \\
Wf-24 & 963 & 894 & 67 & 3 & 0.908 & 0.460 & 0.352 & 0.095 & 0.084 \\
Wf-45 & 1194 & 1199 & 91 & 5 & 1.208 & 0.620 & 0.427 & 0.162 & 0.098 \\
Wf-66 & 1780 & 1606 & 171 & 5 & 1.606 & 0.806 & 0.627 & 0.173 & 0.206 \\
Wf-77 & 2080 & 1826 & 253 & 3 & 1.826 & 0.894 & 0.563 & 0.122 & 0.268 \\
W-43 & 1189 & 1118 & 62 & 9 & 1.235 & 0.579 & 0.270 & 0.386 & 0.157 \\
W-59 & 1677 & 1553 & 118 & 5 & 1.442 & 0.785 & 0.446 & 0.211 & 0.222 \\
W-73 & 2069 & 1855 & 208 & 6 & 1.825 & 0.918 & 0.671 & 0.236 & 0.265 \\
W-88 & 2793 & 2288 & 500 & 6 & 2.350 & 1.105 & 1.105 & 0.230 & 0.329 \\
W-88* & 2793 & 786 & 1989 & 19 & 2.350 & 0.544 & 1.458 & 0.348 & 0.588 \\
\hline
\end{tabular}

Note. Contribution of nanopores $\left(S_{\text {nano }}, V_{\text {nano }}\right)$ at half-width $x<1 \mathrm{~nm}$, mesopores $\left(S_{\text {meso }}, V_{\text {meso }}\right)$ at $1<x<25 \mathrm{~nm}$, and macropores $\left(S_{\text {macro }}, V_{\text {macro }}\right)$ at $x>25 \mathrm{~nm} ; \Delta w$ is the relative deviation of the pore shape from the slitshaped model. *Model with a mixture of slitshaped (relative contribution 0.533 and 0.534 for C-86 and W-88, respectively) and cylindrical $(0.335$ and 0.363$)$ pores and voids between spherical nanoparticles $(0.132$ and 0.103$)$ calculated using the self-consisting regularization procedure. ${ }^{\mathrm{a}} \mathrm{C}-30$ was catalytically activated

As a whole, adsorbents could be of very different morphology (Fig. 4) with various types of porosity dependent on chemical structure, synthesis conditions, activation and other post- synthesis treatments. Activated carbons (AC) despite relatively simple chemical structure (polyaromatics, deformed graphene planes, O-containing functionalities) can possess 
complex PSD strongly dependent on the activation conditions (Table 2). For example, the AC samples with a similar burn-off degree but activated using $\mathrm{CO}_{2}$ (at $1183 \mathrm{~K}$ ) or water vapor in a fixed bed reactor (similar to that used on activation by $\mathrm{CO}_{2}$ and labelled Wf-x, $\mathrm{x}=24$
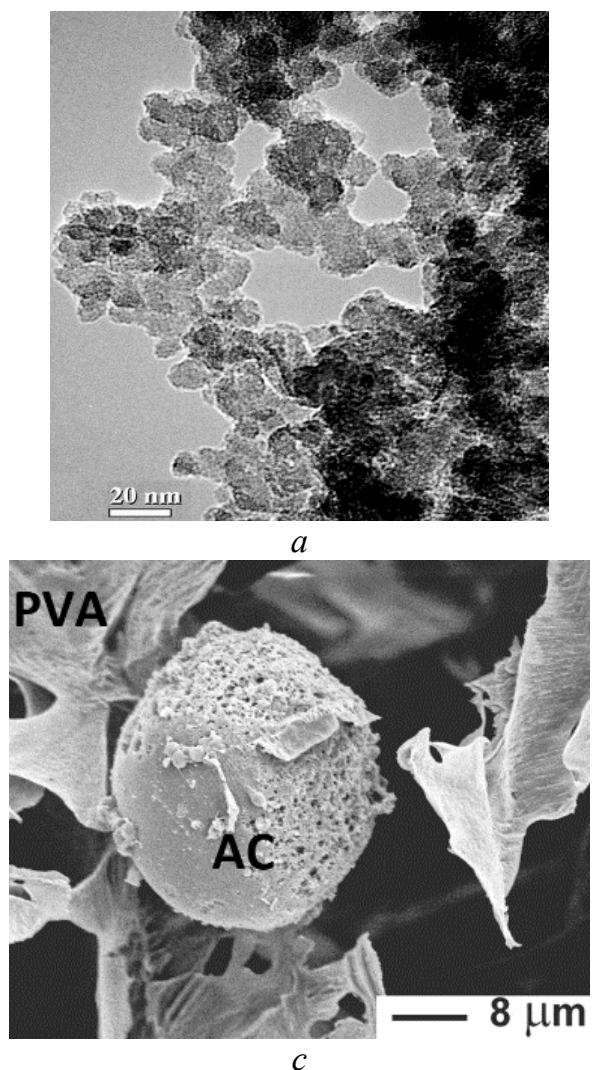

$77 \%$ burn-off) and in a fluidized bed reactor at $1020-1050 \mathrm{~K}$ (labelled W-x, $\mathrm{x}=42.5-88.3 \%$ burn-off at bulk density $0.18-0.10 \mathrm{~g} / \mathrm{cm}^{3}$, respectively) have different textural characteristics (Table 2, Fig. 5).
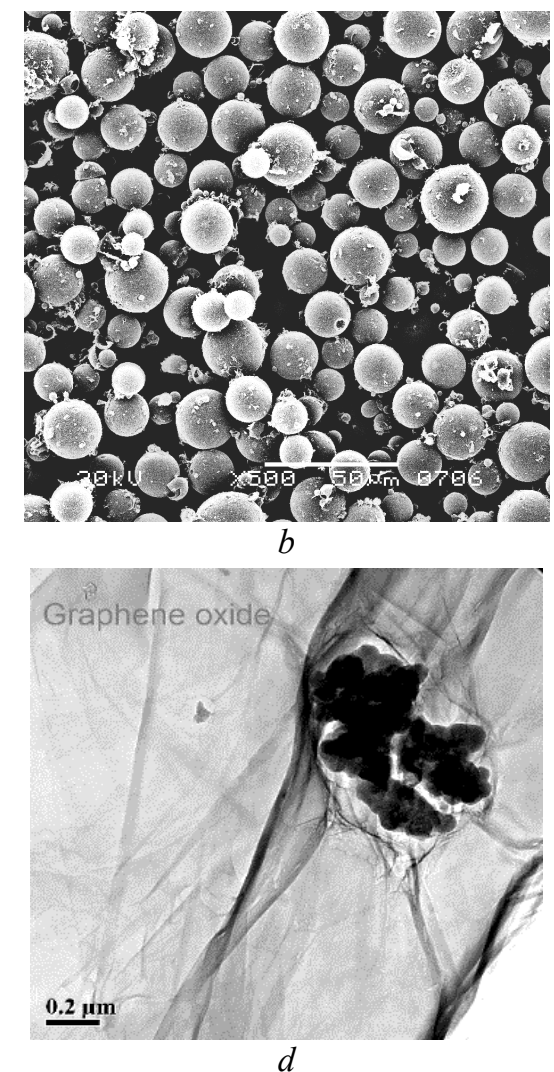

Fig. 4. ( $a, d)$ TEM and $(b, c)$ SEM images of $(a)$ nanosilica, $(b)$ char microparticles, $(c)$ activated carbon/PVA composite, and $(d)$ graphene oxide with a cluster of carbon nanoparticles

Additional information on the characteristics of AC with varied burn-off degree could be obtained upon comparison of the results based on the SAXS and nitrogen adsorption data analyses (Fig. 6), as well SEM (Fig. 7) and TEM (Fig. 8) images (with appropriate quantitative analysis of these images using such specific software as ImageJ/granulometry plugin or Fiji/local thickness plugin) or the adsorption of different probe compounds (Fig. 9) using both adsorption methods and NMR cryoporometry or other methods (e.g. DSC and TG thermoporometry, TSDC relaxometry, etc.).

According to the chord length distribution (CLD) based on the SAXS data for AC with different burn-off degree such as C-0-C-60 (Fig. $6 f$ ), the pore wall thickness is mainly in the range of $0.5-2 \mathrm{~nm}$. This corresponds to two-five carbon sheet stacks with the maximum at $\sim 0.8 \mathrm{~nm}$ corresponding to three layer stacks because the distance between adjacent sheets is close to $0.4 \mathrm{~nm}$. Notice that carbon sheets in AC can be relatively small (in comparison with that in graphite or graphitized materials) and composed of graphene clusters having a structure similar to crumpled paper sheets. One can assume that a simple model of slit-shaped pores may be poorly appropriate for $\mathrm{AC}$ especially with increasing burn-off degree. Therefore, several models of pores (slit-shaped (DFT), cylindrical (DFT) or mixed slit-shaped and cylindrical pores (S/C, NLDFT) and voids between spherical particles (V method) and two different methods (nitrogen adsorption and SAXS) were applied here for textural characterization of the materials $[14,39]$. 
The overall shape of pores in AC is complex because there are several types of pores can be found. The narrowest pores of the slit-shaped type can be inner pores in carbon nanoparticles (Fig. 7) [11, 14, 38, 39]. The structure of sheets in these nanoparticles could be non-planar (Fig. 8) due to structural traces of a polymer precursor, and since the temperature of activation was lower than that of graphitization. Therefore, nanopores can have a non-ideal slitshaped structure. Carbon nanoparticles of a

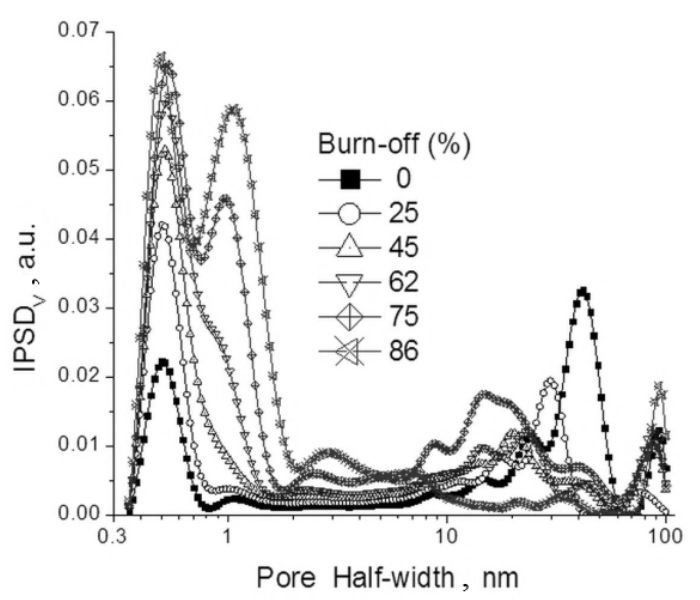

$a$ random structure (roughly described as spherical) form aggregates (Fig. 7). Pores in these aggregates are not of a slit-shaped type and can include motives of voids between spherical particles, slit-shaped, wedge-shaped, cylindrical and spherical pores. Thus, a complex model of pores (e.g. SCV/SCR) could be more appropriate than a simple one. However, there is good agreement between the DFT (slit-shaped pore model) and SAXS PSD (Fig. 6).

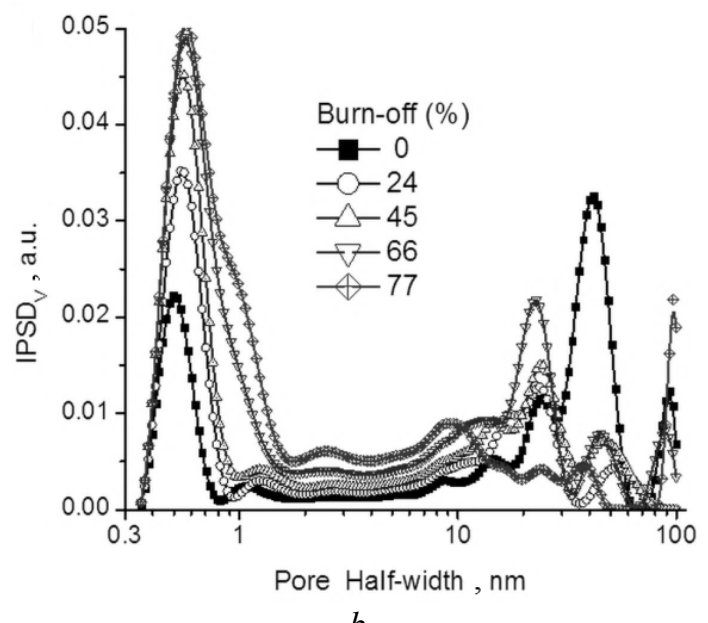

$b$

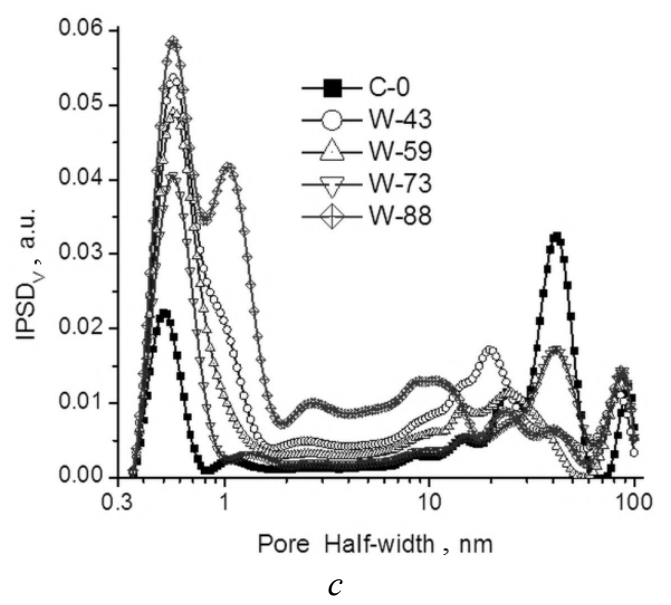

Fig. 5. Incremental $\mathrm{PSD}_{\mathrm{V}}$ for carbon samples activated by $(a) \mathrm{CO}_{2}$ and water vapor in $(b)$ fixed and $(c)$ fluidized bed reactors, DFT method with the model of slitshaped pores [39]

Despite certain differences in the shapes of these PSD, the positions of the main peaks are similar. Notice that the SAXS PSD were calculated with unfixed regularization parameter $(\alpha)$ that results in the $\alpha$ values smaller than 0.01 but $\alpha=0.01$ was fixed on the DFT calculations. Therefore, at $x>40 \mathrm{~nm}$ there are two SAXS
PSD peaks, but the DFT PSD has only one peak there [14].

The character of changes in the PSD of nanopores and macropores with increasing burnoff degree is simpler than that of changes in the PSD of mesopores (Fig. 6). The SAXS and DFT PSD clearly demonstrate the opposite changes 
for narrower $(2<x<7 \mathrm{~nm})$ and broader $(7<x<15 \mathrm{~nm}$ ) mesopores (Fig. $6 e$ ).

The character of pore filling by different probes depend not only on the size of probe molecules but also on their chemical structure as well the pore walls. For example, water molecules can remain in mesopores of $\mathrm{AC}$
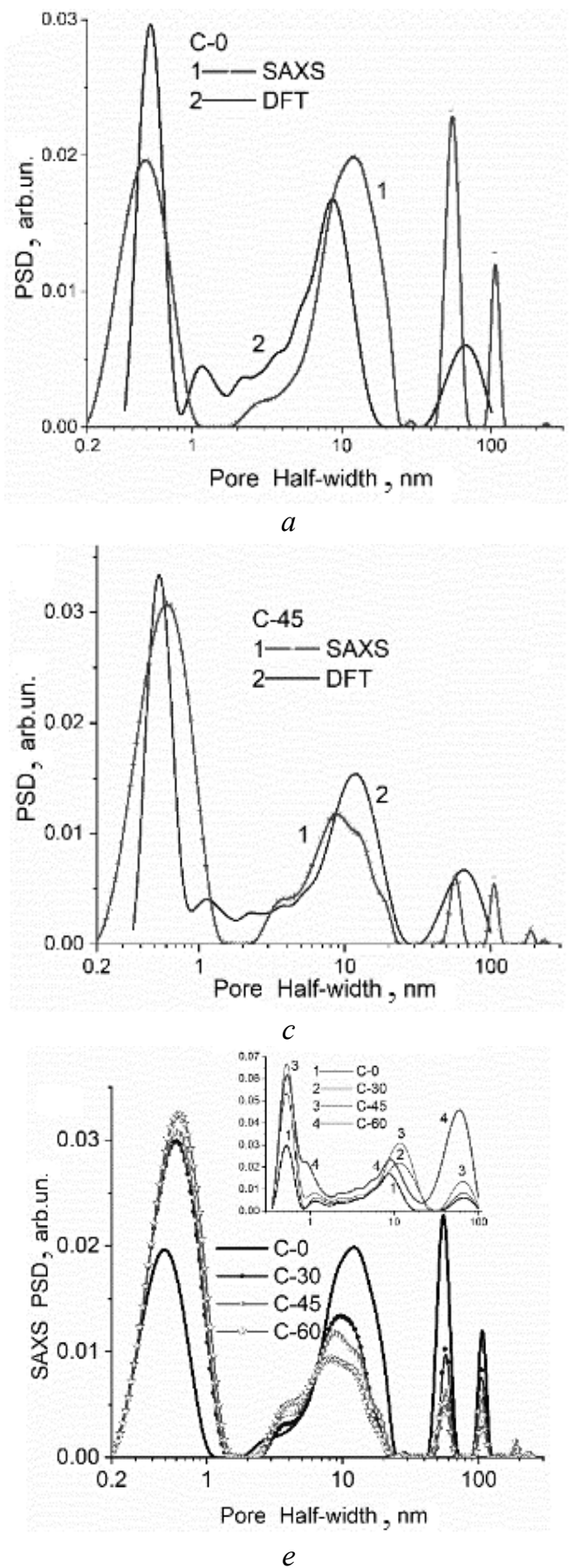

around polar O-containing functionalities (located at the edges of carbon sheets forming nanopores), and, therefore, nanopores are practically free of water. Typically, the adsorption isotherms of water on $\mathrm{AC}$ are characterized by small values at low pressures [11].

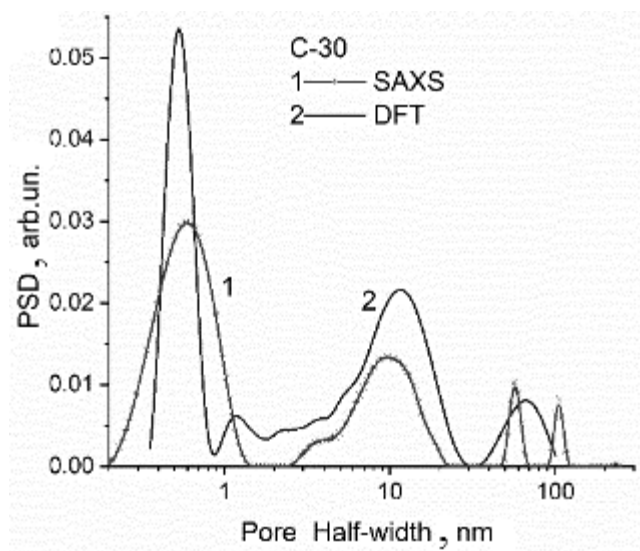

$b$

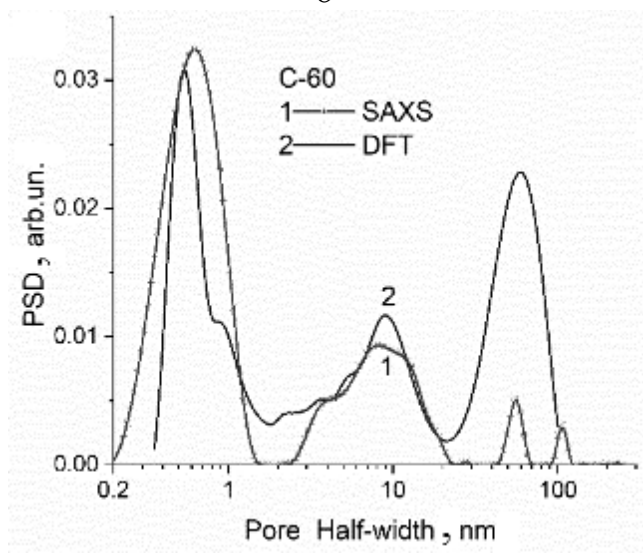

$d$

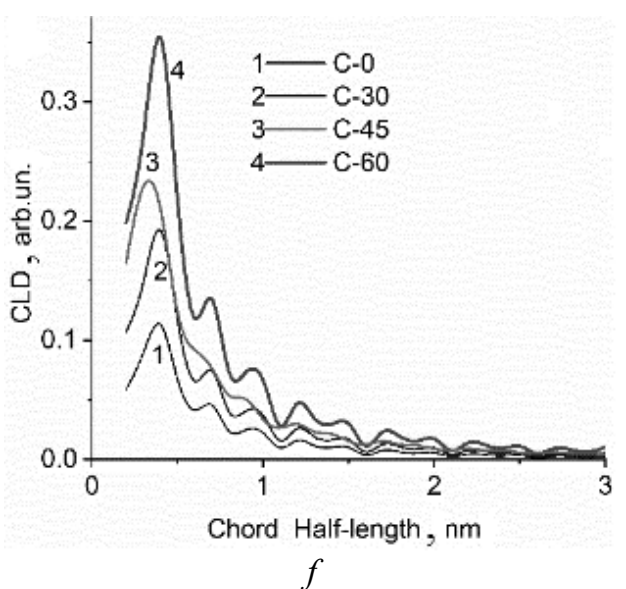

Fig. 6. SAXS and $\mathrm{N}_{2}$ DFT pore size distributions for $(a)$ C- 0 , (b) C-30, (c) C-45, (d) C-60; and PSDs for these ACs with (e) SAXS and (insert in $e$ ) $\mathrm{N}_{2}$ DFT; and $(f)$ chord length distributions [14] 


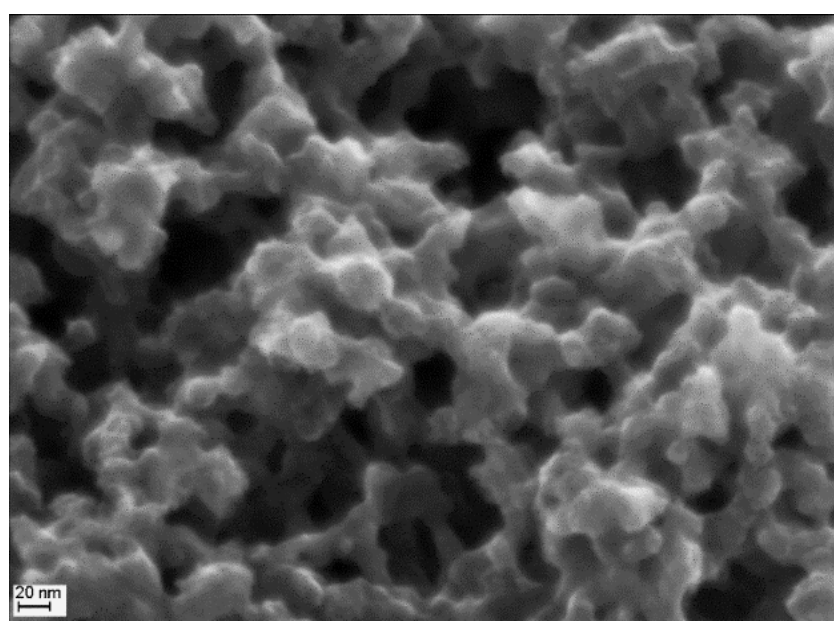

Fig. 7. SEM image of $\mathrm{AC}[40,41]$ (scale bar $20 \mathrm{~nm}$ )
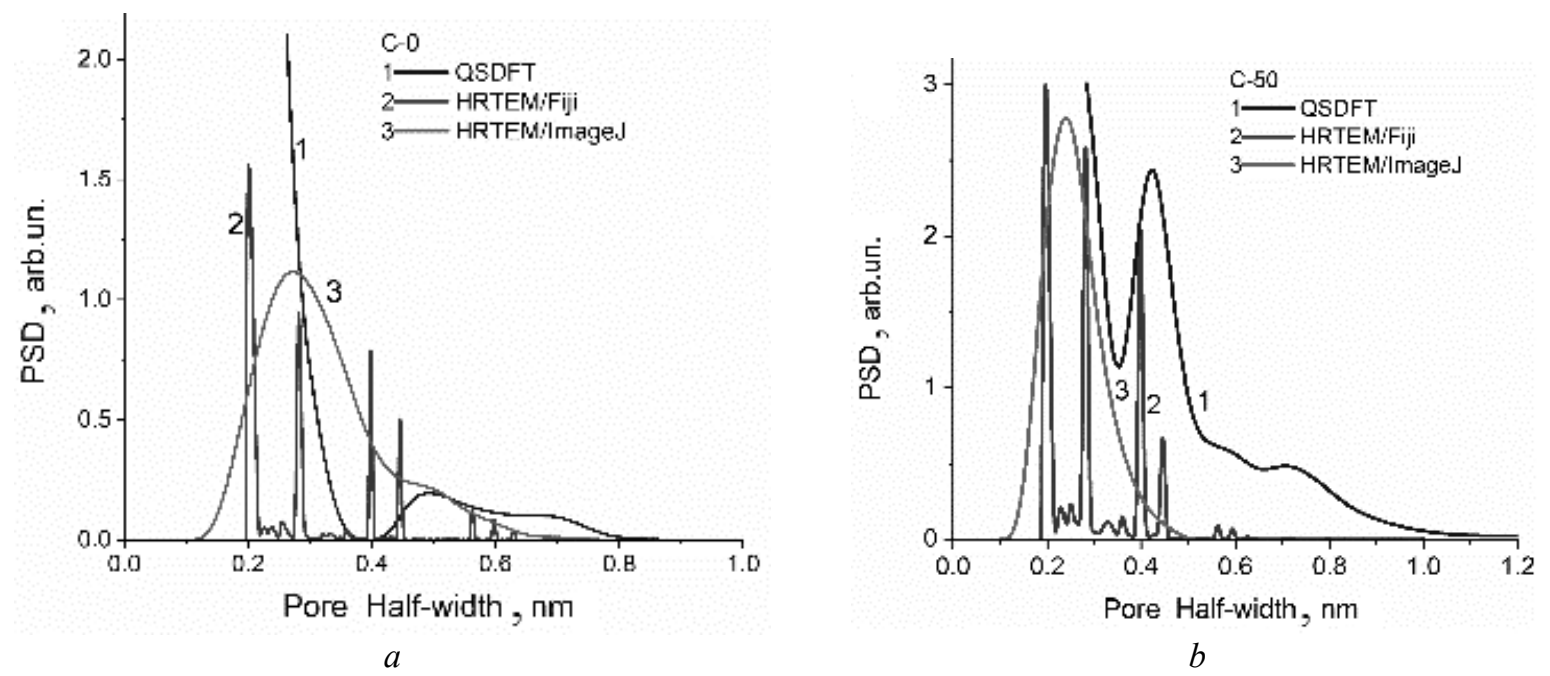

Fig. 8. Pore size distributions for activated carbons $(a)$ C-0 $\left(S_{\mathrm{BET}}=590 \mathrm{~m}^{2} / \mathrm{g}\right)$ and $(b)$ C-50 $\left(S_{\mathrm{BET}}=1664 \mathrm{~m}^{2} / \mathrm{g}\right)$ calculated using QSDFT (nitrogen ads-des isotherm) and from HRTEM images using ImageJ (granulometry plugin) and Fiji (local thickness) program suits [38]

NMR cryoporometry could give a peak of PSD determined for unfrozen water (Fig. $9 d$ ). However, this water can be located in broad pores because melting of ice occurs layer-bylayer in broad pores. In other words, ice crystallites could form secondary porosity in broad pores. Therefore, water is rather inappropriate probe for NMR cryoporometry, especially for AC [11]. Nonpolar probes located in pores independent on the chemical structure of the pore walls (because of nonspecific van-derWaals interactions) are more appropriate for NMR cryoporometry or relaxometry as well DSC thermoporometry.
The textural characterization becomes much more complex for nonuniform and composite materials. Various mixtures of silica gel Si-60, nanosilica A-200, AC (PS1) and carbon black (Envicarb) were used as models of complex materials [12]. The nitrogen adsorptiondesorption isotherms have complex shapes for their various mixtures (Fig. 10).

Preparation of these mixtures were carried out with no strong mechanical loading. Therefore, the mixtures demonstrate additivity with respect to the nitrogen adsorption (Fig. 11). In other words, pores of different components in the mixtures remain accessible for nitrogen molecules as in the initial materials alone. 


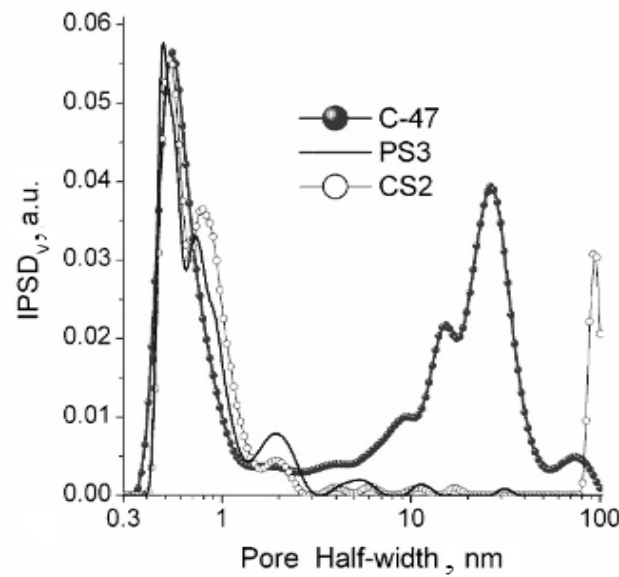

$a$

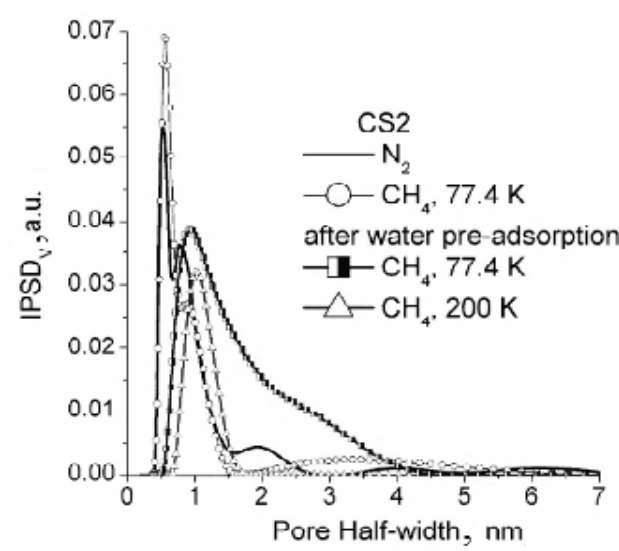

$c$

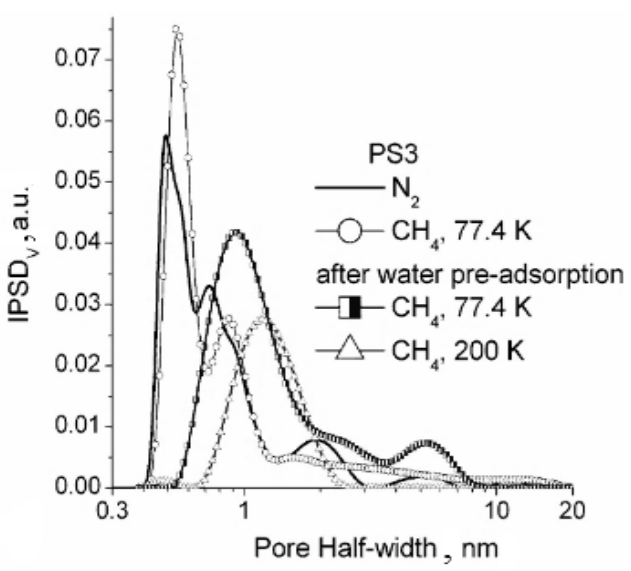

$b$

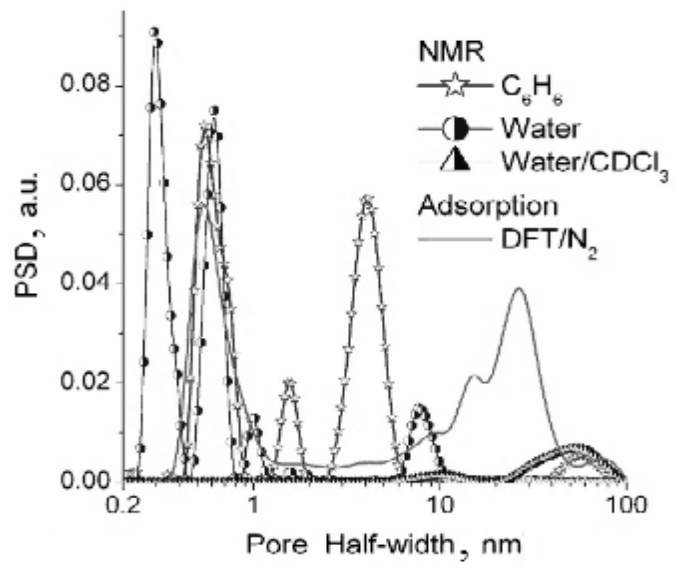

$d$

Fig. 9. DFT incremental pore size distributions for activated carbons (a) C-47 (Mast Carbon Technology Ltd, $47 \%$ burn-off), PS3 (from plume stones) and CS2 (from coconut shells) calculated on the basis of the $\mathrm{N}_{2}$ adsorption data; and (b) PS3 and (c) CS2 calculated on the basis of the $\mathrm{N}_{2}(77.4 \mathrm{~K})$ and $\mathrm{CH}_{4}(77.4$ and $200 \mathrm{~K}$ ) adsorption data without and with pre-adsorbed water; and $(d)$ size distribution functions of structures with unfrozen liquids calculated with integral Gibbs-Thomson equation and NMR cryoporometry for adsorbed water (alone and with the presence of chloroform- $d$ ) and benzene, and DFT PSD on the basis of nitrogen adsorption on carbon C-47 [11, 39, 42]
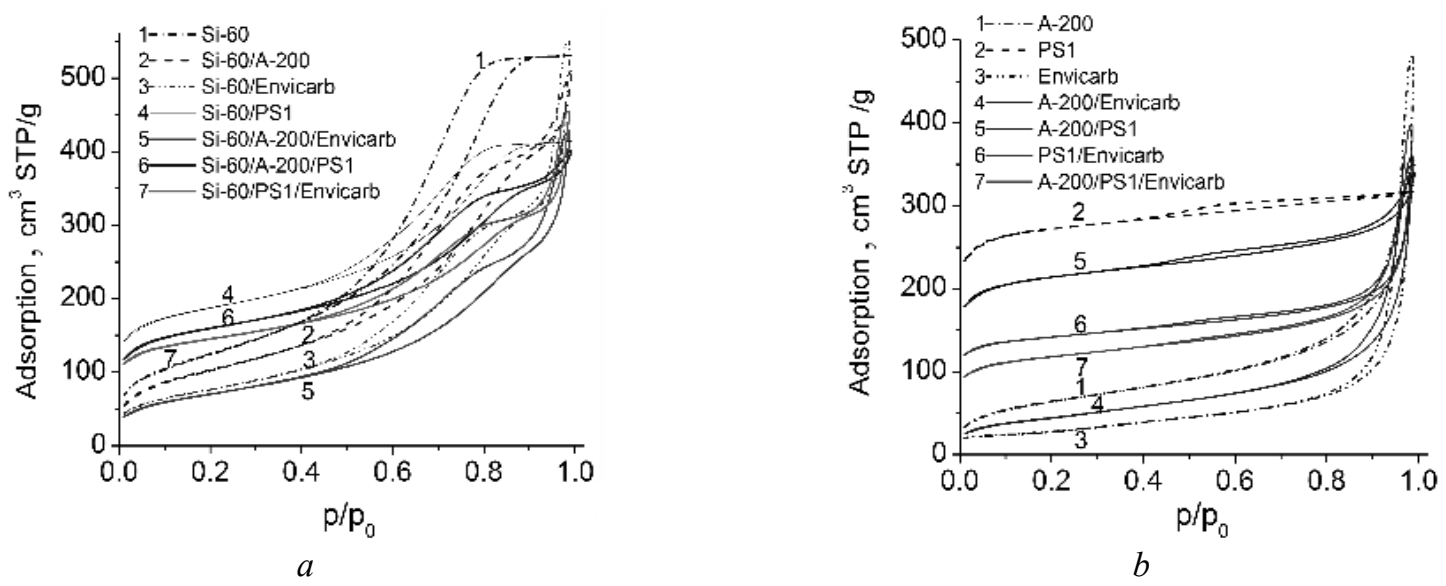

Fig. 10. Nitrogen adsorption-desorption isotherms for individual adsorbents (a) Si-60 and (b) A-200, PS1 and Envicarb and $(a, b)$ their binary and ternary mixtures [12] 

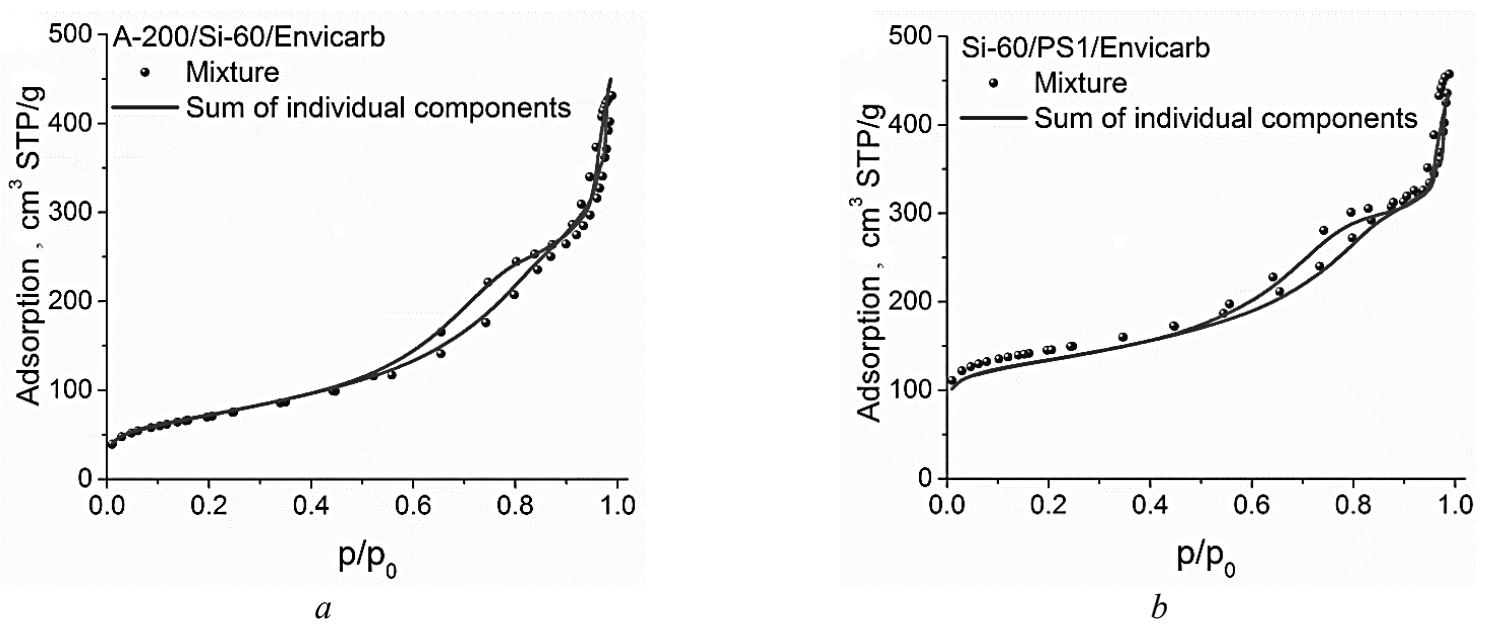

Fig. 11. Nitrogen adsorption-desorption isotherms for mechanical mixtures (symbols) (a) A-200/Si-60/Envicarb and $(b)$ Si-60/PS1/Envicarb and the corresponding normalized sums of the isotherms for individual components (lines) [12]

Application of the standard approaches with firm software (e.g. NLDFT, QSDIF, BJH and other methods from Quantachrome software) give much worse results than those of the SCV/SCR method (Fig. 12). There are several reasons of poor results of firm software: (i) absence of the possibility of the use of the parameters for different materials (e.g., silica, carbon, etc.) in complex systems; (ii) a restricted set of pore models as well probe types; and (iii) absence of self-consistent regularization. The developed SCV/SCR method [12] has not these disadvantages; therefore, it can be effectively used to analyze complex materials. Additional advantage of the SCV/SCR method is the possibility to evaluate the contributions of different pores of different materials in complex systems.

The adsorption of various probes under different conditions can give information on the behavior of adsorbents and adsorbates in different applications. For example, both nitrogen and propane isotherms have open hysteresis loops upon adsorption onto multiwalled carbon nanotubes (CNT) (Fig. $13 a$ ) [43]. This can be explained by the gas adsorption in the interior of closed carbon nanotubes through nanopores (defects) in the tube walls. The volume of these nanopores is low, but their contribution to the specific surface area is significant. The inside radius of CNT corresponds to mesopores. Additionally, the space between CNT provides the textural porosity of CNT clots, which corresponds to meso- and macropores. The adsorption of gases inside and outside of CNT results in broad PSD at $x>5 \mathrm{~nm}$ (Fig. $13 c$ ).

Propane (boiling point $231 \mathrm{~K}$ ) can be adsorbed at $273 \mathrm{~K}$ (temperature of adsorption measurements [43]) only in narrow pores. Therefore, its main PSD peak is at $x<2 \mathrm{~nm}$ (Fig. 13 e). However, it can penetrate (but slowly) in the interior of CNT (the hysteresis loops are open). Therefore, there are small PSD peaks at $x>2 \mathrm{~nm}$.

The total adsorption of propane is much smaller than that of nitrogen because of the difference in their location. Propane molecules, in contrast to nitrogen ones, ignore the textural porosity between CNT and weakly fill the inner space of CNT. There is a certain structural difference between CNT $(1.22$ at. \% O), additionally oxidized $\mathrm{CNT}_{\text {ox }}(2.06$ at. \% O) and $\mathrm{N}-\mathrm{CNT}(1.11$ at. $\% \mathrm{O}$ and 0.62 at. $\% \mathrm{~N}$ ) over the total range of pores (Fig. 13). Additionally, $\mathrm{CNT}_{\text {ox }}$ and N-CNT are characterized by larger deviations of the pore shape from the models. Slit-shaped pores can be located in and between the tube walls of multi-walled CNT. Their contribution is smaller than that of cylindrical pores. Therefore, for CNT, a model criterion $\Delta w_{\text {cyl }}<\Delta w_{\text {slit }}$ and the $\Delta w_{\text {cyl }}$ value correspond to approximately $6 \%$ deviation of the pore shape from the model of cylindrical pores [43].

For nanosilicas (as materials with purely textural porosity), there are well established correlations between the average size of primary nanoparticles and the specific surface area 
$[2,11]$. However, the particle size distributions (PaSD, $\varphi(a)$ ) could be different for the materials with similar values of $S_{\text {BET. }}$ Therefore, information on PaSD is of interest and important from a practical point of view. The PaSD could be estivated from (i) images of high-resolution microscopic methods (TEM, SEM, AFM) using

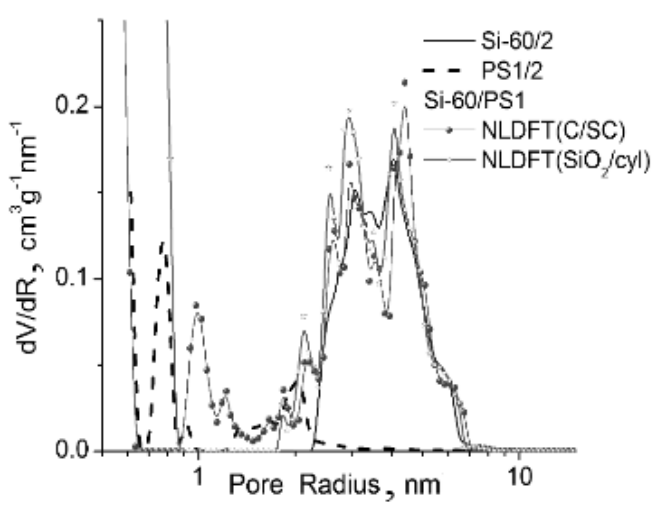

$a$

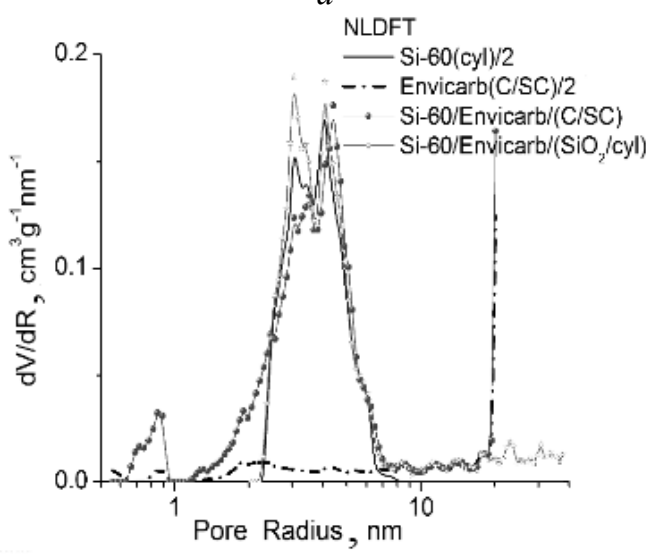

C

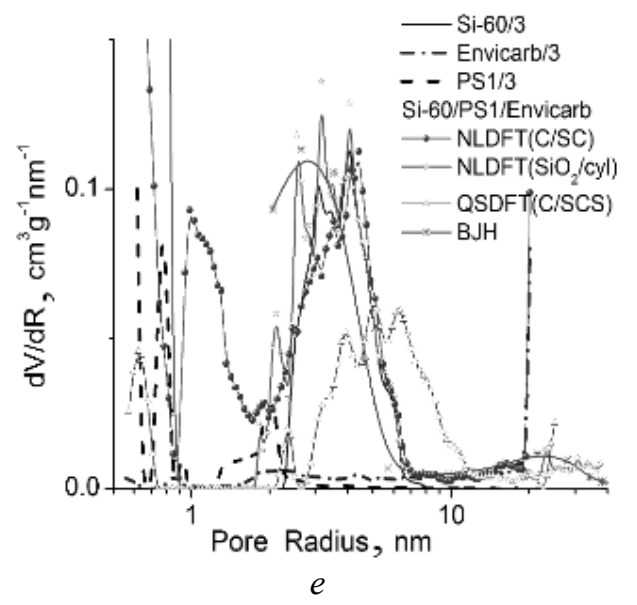

specific software, (ii) SAXS measurements, and (iii) nitrogen adsorption data using $\mathrm{V} / \mathrm{SCR}$ method (Fig. 14) and the $S_{\varphi}$ and $S_{\mathrm{BET}}$ values as described above. As a whole, all these methods give similar PaSD. The latter is simpler but more informative approach, because it gives both PSD (Fig. $14 a$ ) and PaSD (Fig. $14 b$ ) in parallel.
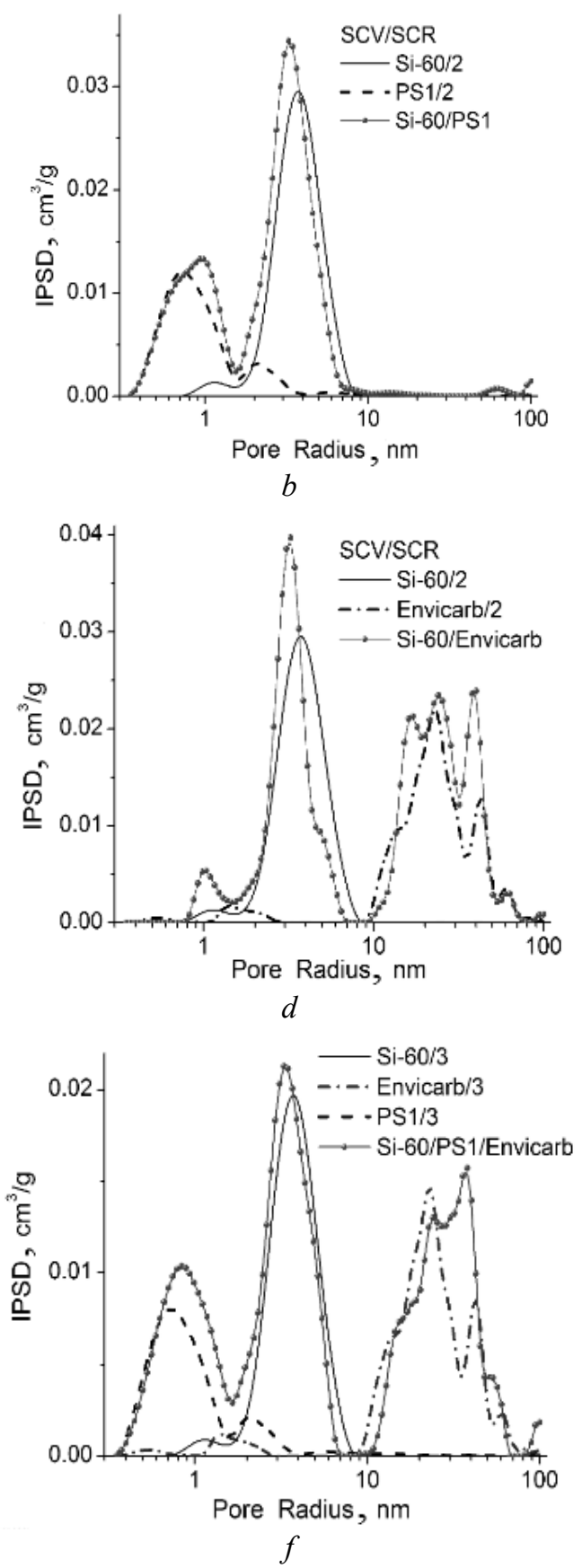

Fig. 12. NLDFT or QSDFT or BJH differential PSD $(a, c, e)$ and SCV/SCR incremental PSD $(b, d, f)$ for $(a, b)$ normalized sum of individual Si-60, PS1 and a mixture Si-60/PS1; $(c, d)$ normalized sum of individual Si60, Envicarb and a mixture Si-60/Envicarb; and ( $e, f)$ normalized sum of individual Si-60, Envicarb, PS1 and a mixture Si-60/PS1/Envicarb (PSDs for individual components in the sums were divided by $(a-d) 2$ or $(e, f) 3)[12]$ 

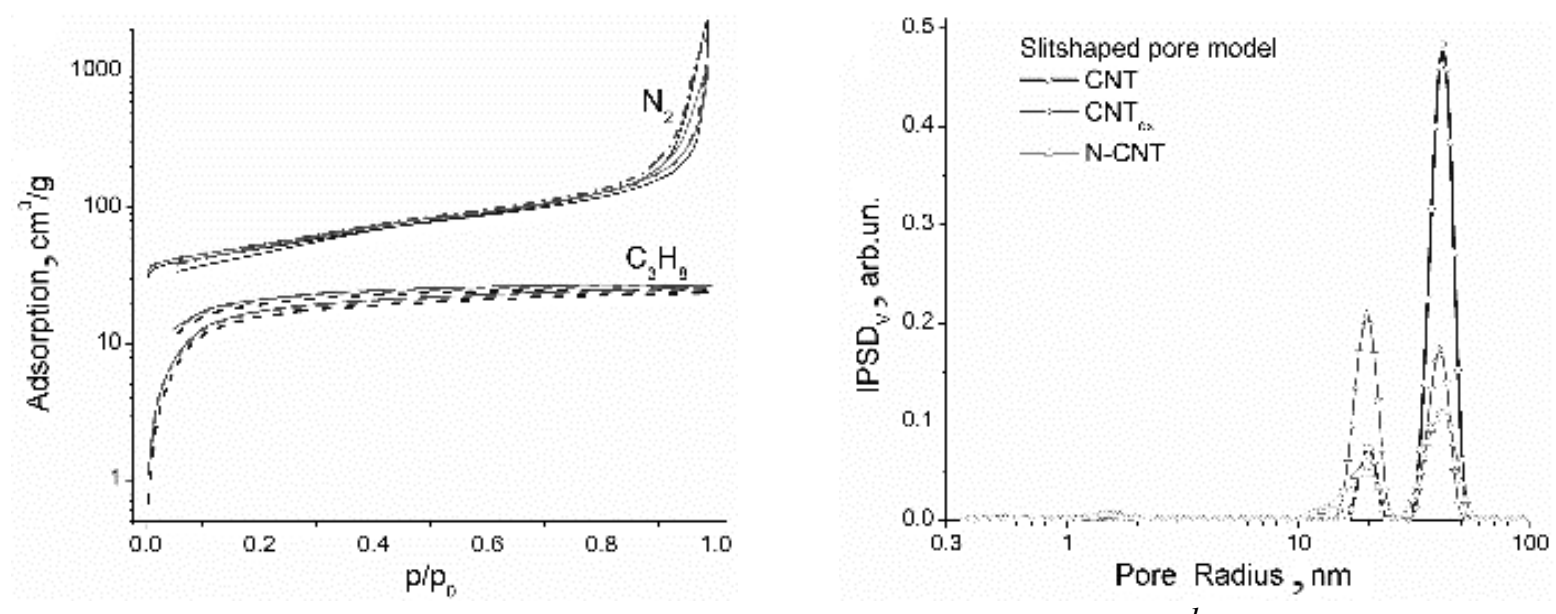

$a$

$b$
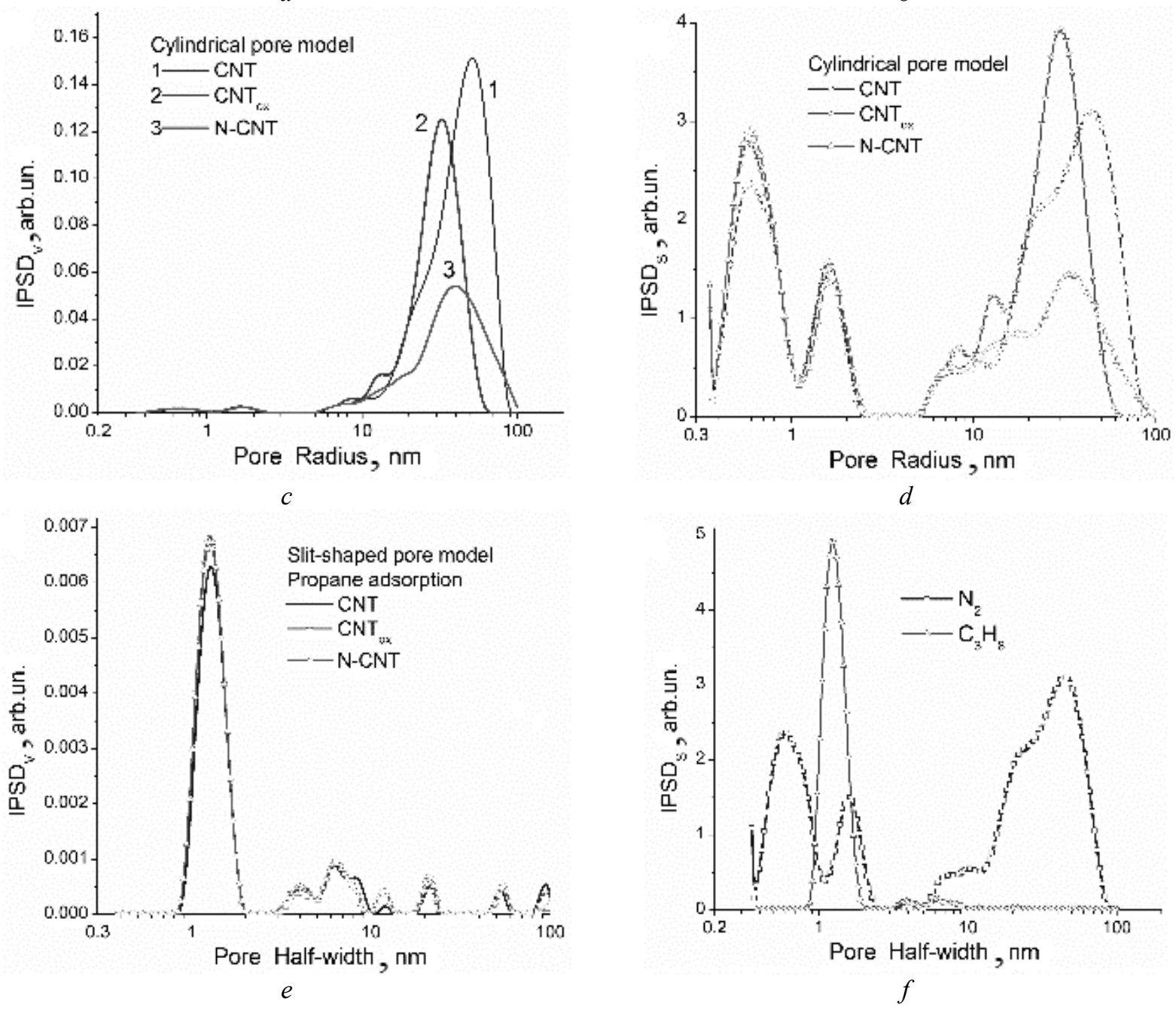

Fig. 13. (a) Adsorption-desorption isotherms of nitrogen $(77.4 \mathrm{~K})$ and propane $(273 \mathrm{~K})$; slit-shaped pore model with the SCV method used for $(b)$ nitrogen desorption and $(e)$ propane adsorption; $(c, d)$ cylindrical pore model with Eq. (2) (DFT) with respect to $(c)$ the pore volume and $(d)$ specific surface area; $(f) \operatorname{IPSD}_{\mathrm{S}}$ for CNT using the nitrogen (DFT) and propane (SCV) ads.-des. isotherms [43] 

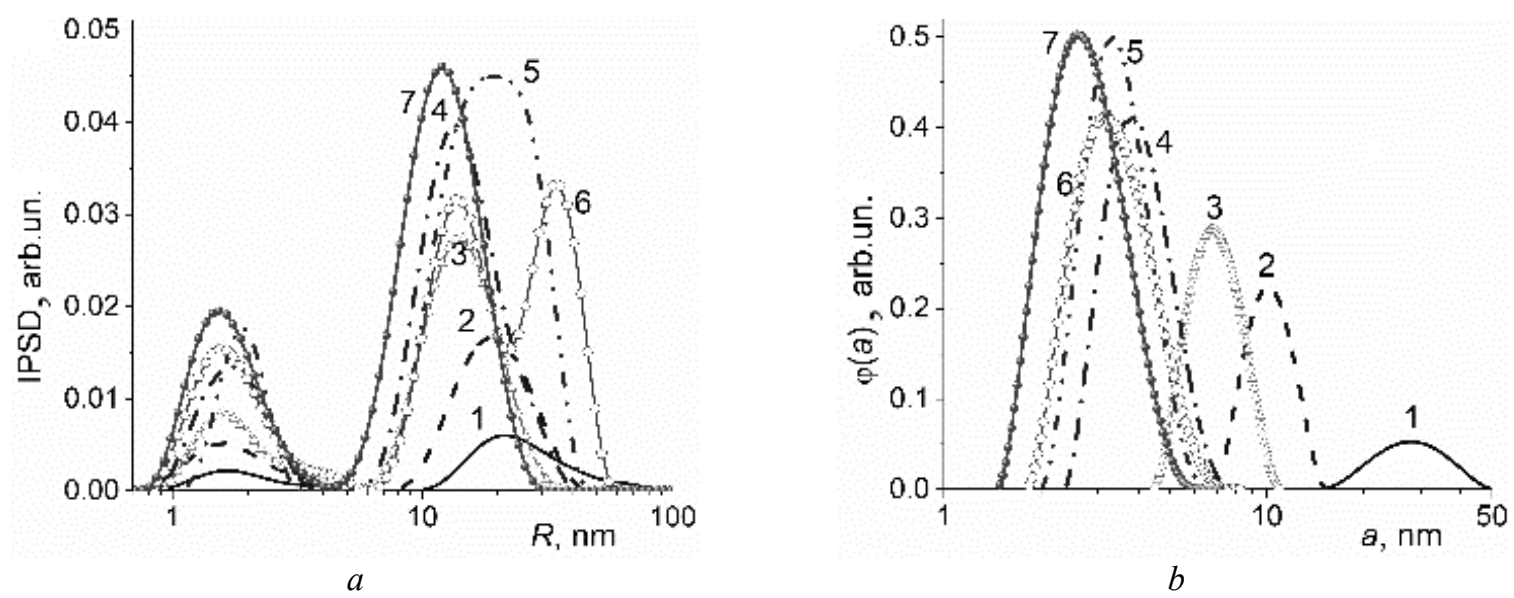

Fig. 14. Incremental PSD $(a)$ and particle size distributions $(b)$ for fumed silicas A-50 (1), A-150 (2), A-200 (3), A-300 (4), A-380 (5), A-400 (6) and A-500 (7); model of voids between spherical particles at condition $S_{\varphi} \approx S_{\mathrm{BET}}$ and average deviation. $\left(S_{\varphi}-S_{\mathrm{BET}}\right) / S_{\mathrm{BET}}< \pm 0.01[11]$

Note that the SAXS method gives more complex PaSD (Fig. 15) than that of V/SCR (Fig. $14 \mathrm{~b}$ ) because the former gives information not only on primary NPNP but also on their aggregates that is caused by features of SAXS. Thus, for the morphological/textural analysis of fumed oxides, it is better to use the data of both approaches giving a more comprehensive picture on the characteristics studied [44].

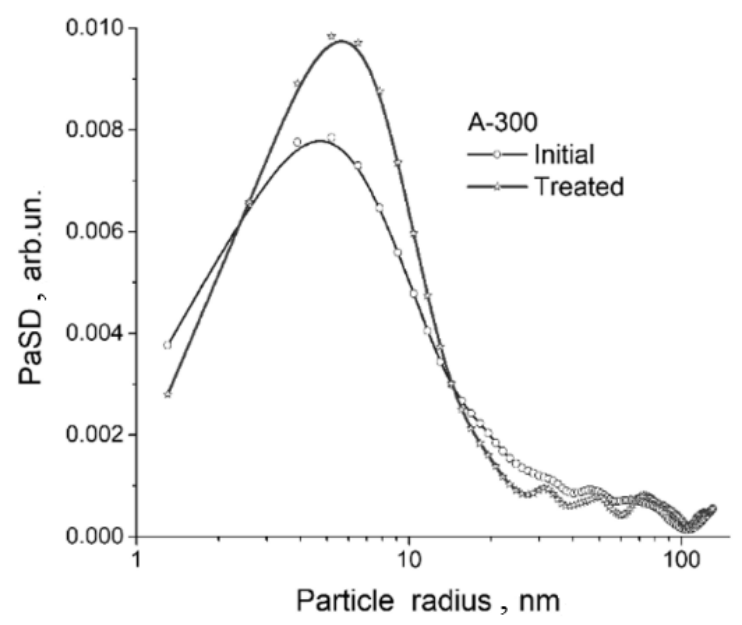

Fig. 15. SAXS PaSD of initial and wetted-dried nanosilica A-300 [28, 44]

Upon the analysis, one should remember that SAXS gives information on both accessible and inaccessible (closed) pores. This is clear visible from comparison of PSD calculated using SAXS, NLDFT and SCV/SCR methods for initial and wetted-dried nanosilica [44], especially in the range of nanopores.
The IR spectroscopy could be used to estimate not only the specific surface area (Table 3) using several approaches but also the surface content of silica in complex fumed oxides [18]. This estimation could be accurate upon the use of dry silicas because adsorbed water can affect the IR surface modes and can cause some other rather negative effects [18].

Table 3. Specific surface area of silicas estimated from the IR spectra and nitrogen adsorption isotherms [18]

\begin{tabular}{lccc}
\hline \multicolumn{1}{c}{ Silica } & $\begin{array}{c}\boldsymbol{S}, \mathbf{~ m}^{2} / \mathbf{g} \\
\mathbf{E q . ~ ( 1 9 )}\end{array}$ & $\begin{array}{c}\boldsymbol{S}, \mathbf{~ m}^{2} / \mathbf{g} \\
\mathbf{E q . ~ ( 2 0 )}\end{array}$ & $\begin{array}{c}\boldsymbol{S}_{\text {BET, }} \\
\mathbf{m}^{2} / \mathbf{g}\end{array}$ \\
\hline A-50 & 66 & 66 & 52 \\
A-150 & 129 & 130 & 134 \\
A-200(I) & 185 & 183 & $200^{\text {a }}$ \\
A-200(II) & 194 & 191 & $200^{\text {a }}$ \\
A-300(I) & 289 & 294 & 302 \\
A-300(II) & 326 & 334 & 330 \\
A-500 & 532 & 548 & 492 \\
OX-50* & 50 & 49 & 54 \\
A-300* & 299 & 306 & $300^{\text {a }}$ \\
TS-100* & 262 & 263 & $250^{\text {a }}$ \\
\hline
\end{tabular}

Note. *Degussa silica; ${ }^{\mathrm{a}} S_{\mathrm{BET}}$ according to firm information. Numbers (I) and (II) correspond to silicas from different sample parties (to record the IR spectra, all samples were mixed with $\operatorname{KBr}(1: 400)$ and treated in the microbreaker for $5 \mathrm{~min})$. A band at $1100 \mathrm{~cm}^{-1}$ was decomposed into two bands at $1100 \mathrm{~cm}^{-1}$ (TO phonon mode, $w_{1}$ ) and $1200 \mathrm{~cm}^{-1}$ (LO phonon mode, $\left.w_{2}\right), x=w_{2} / w_{1}$ 
The DSC and TG thermoporometry methods could be used if one need information on the behavior of adsorbents at different (low and high) temperatures upon interaction with various adsorbates (Fig. 17).

Comparison of DSC (n-decane) and TG (water) PSD with NLDFT PSD (nitrogen) shows that the shapes of PSD of mesopores are relatively similar (Fig. 17). However, larger molecules of decane cannot effective penetrate into narrow pores in which nitrogen or water molecules can penetrate (Fig. $17 \mathrm{a}$ ). Water is evaporated from narrow pores with a certain delay $(\mathrm{Si}-40)$ in comparison with that for broader pores (Si-100). Thus, the use of several methods for the textural characterization of silica gels could be recommended, but upon the studies all aspects should be analyzed in detail to consider features of each used method.
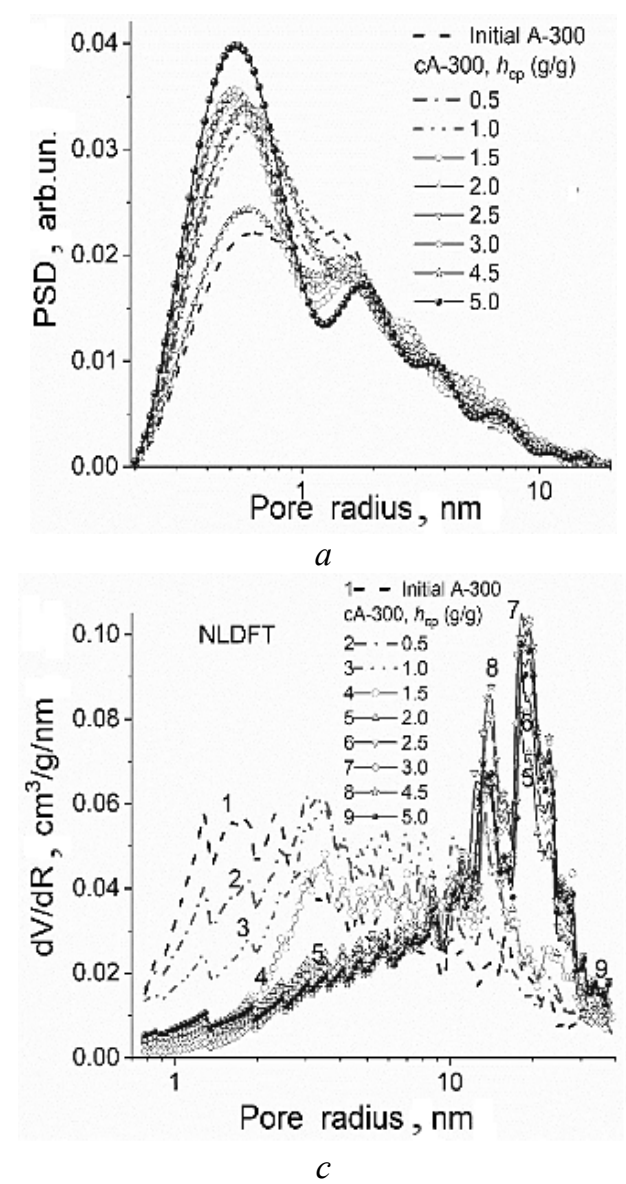

Silica gels are more rigid adsorbents, whose PSD depend weakly on the measurement conditions (Fig. 17) [11], in comparison, e.g., with porous polymers [45]. A textural weakness (or flexibility, or swelling) of porous polymers depends on several factors: (i) cross-linking degree, (ii) chemical structure (hydrophilicity-hydrophobicity), (iii) the nature of adsorbates, and (iv) conditions. Soft (Fig. $18 a$ ) and rigid (Fig. $18 b$ ) polymers are frequently hydrophilic and hydrophobic, respectively. However, hydrophobic porous polymers with a low degree of cross-linking could be well swollen in hydrophobic solvents, but this effect could be smaller than that for hydrophilic polymers swollen in water. These aspects could be controlled using hydrophilic fillers for hydrophobic polymers (Fig. 19) or hydrophobic fillers for hydrophilic polymers with varied changes in the cross-linking degree $[11,15,40,41,46]$.
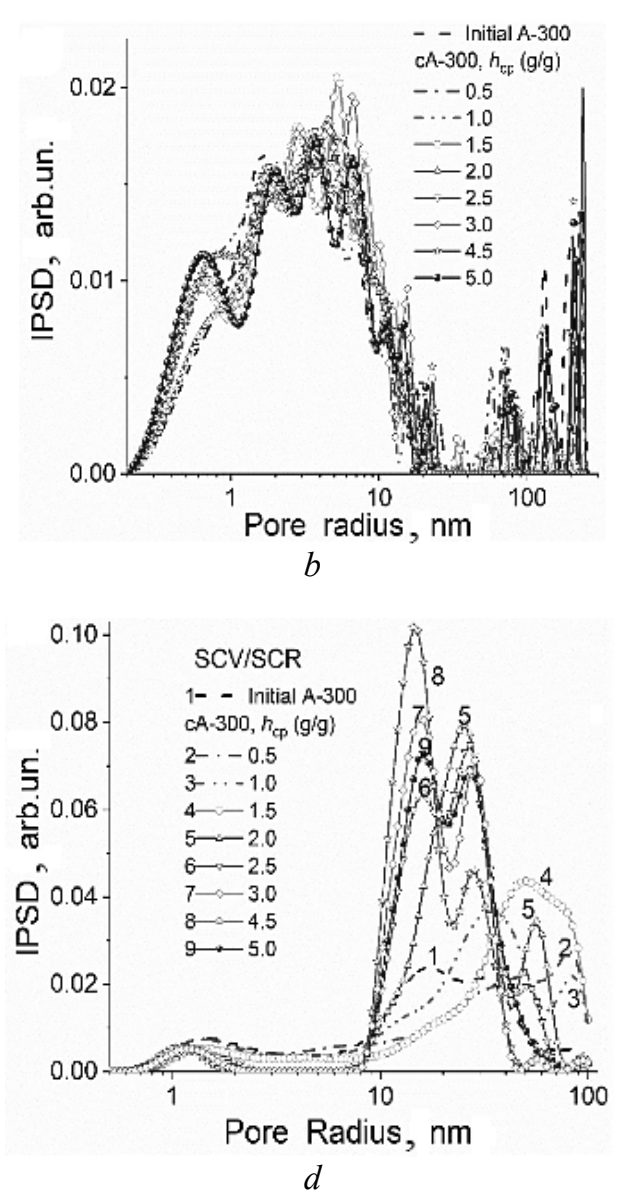

Fig. 16. Pore size distributions $(a, c)$ differential and $(b, d)$ incremental calculated using $(a, b)$ SAXS and $(c, d)$ nitrogen adsorption-desorption isotherms with $(c)$ NLDFT and $(d)$ SCV/SCR methods for initial and hydro-compacted A-300 [44] 


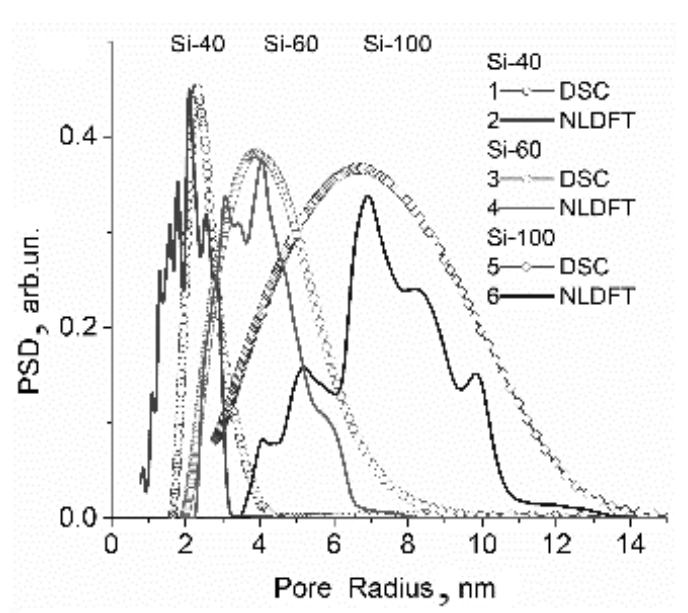

$a$

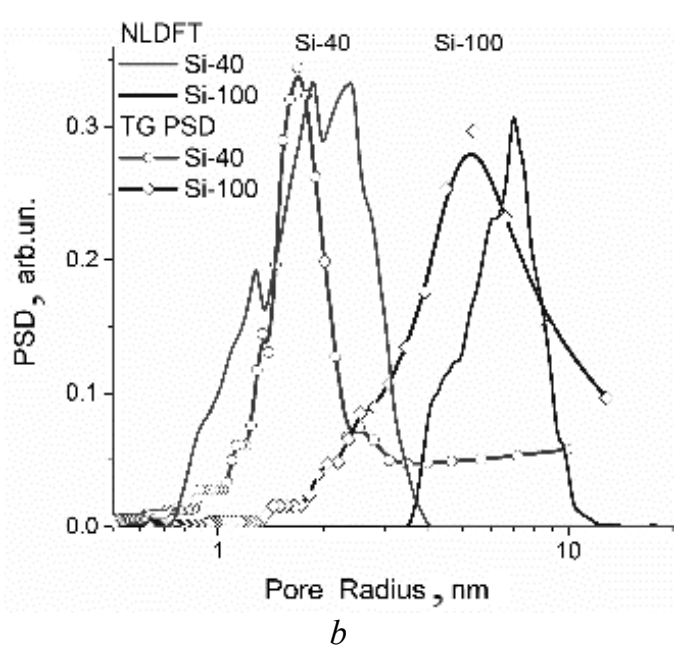

$b$

Fig. 17. Differential PSDs of silica gels calculated using (a) NLDFT method (nitrogen adsorption-desorption isotherms, cylindrical pore model) and the Gibbs-Thomson equation for the freezing point depression for $n$-decane confined in pores Si-40 $\left(S_{\mathrm{BET}}=742 \mathrm{~m}^{2} / \mathrm{g}, \quad V_{\mathrm{p}}=0.64 \mathrm{~cm}^{3} / \mathrm{g}\right), \quad$ Si- $60 \quad\left(S_{\mathrm{BET}}=456 \mathrm{~m}^{2} / \mathrm{g}\right.$, $\left.V_{\mathrm{p}}=0.82 \mathrm{~cm}^{3} / \mathrm{g}\right)$, and Si-100 $\left(S_{\mathrm{BET}}=349 \mathrm{~m}^{2} / \mathrm{g}, V_{\mathrm{p}}=1.23 \mathrm{~cm}^{3} / \mathrm{g}\right)$ using DSC melting thermograms [35]; and $(b) \mathrm{N}_{2}$ NLDFT and thermoporometry based on the TG data for water desorbed from Si-40 $\left(S_{\mathrm{BET}}=785 \mathrm{~m}^{2} / \mathrm{g}, V_{\mathrm{p}}=0.58 \mathrm{~cm}^{3} / \mathrm{g}\right)$ and $\mathrm{Si}-100\left(S_{\mathrm{BET}}=314 \mathrm{~m}^{2} / \mathrm{g}, V_{\mathrm{p}}=1.07 \mathrm{~cm}^{3} / \mathrm{g}\right)[16]$
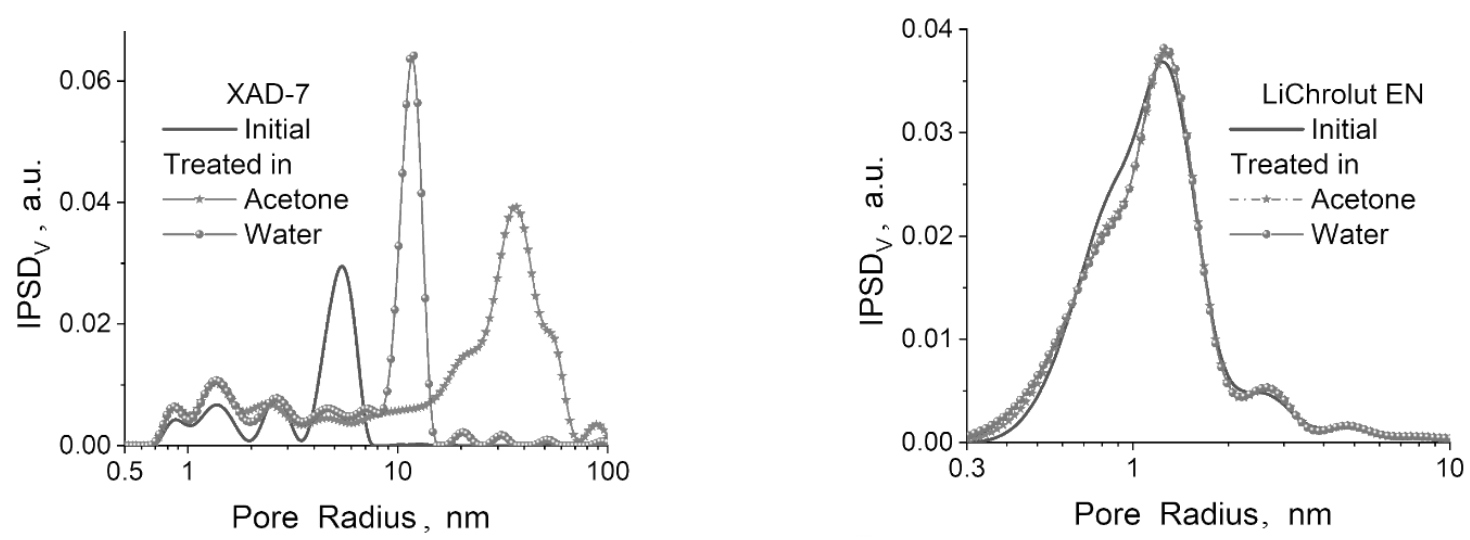

Fig. 18. Shaking of samples in ultrasonic bath $(\sim 2 \mathrm{~min})$, storage for $24 \mathrm{~h}$, freezing in liquid nitrogen $(2 \mathrm{~h})$, filtration, drying under mild conditions then at $353 \mathrm{~K}$ in air; and degassing in vacuum at $353 \mathrm{~K}$ before nitrogen adsorption-desorption measurements: (a) Amberlite XAD-7 (acrylic ester polymer) at $S_{\mathrm{BET}}=341$ (initial), 462 (treated in acetone), 488 (water) $\mathrm{m}^{2} / \mathrm{g}$ and $(b)$ LiChrolut EN (copolymers of styrene and divinylbenzene) at $S_{\mathrm{BET}}=1512$ (initial), 1479 (treated in acetone), 1521 (water) $\mathrm{m}^{2} / \mathrm{g}$ [45]

Comparison of the PSD calculated using the SAXS and SCV/SCR methods for porous polymer particles shows that a significant part of narrow pores is inaccessible for nitrogen molecules as well in the case of silicas or AC above analyzed. This aspect could be controlled by changes in the composition and synthesis techniques of complex porous polymer particles [46]. It should be noted that some of the described above methods (e.g. NMR, DSC,
CLSM, etc.) could be effectively applied to native (live) hydrated systems to analyze their morphological and textural features [11].

The structure of cells depends strongly on the degree of hydration that is well seen for differently hydrated yeast cells studied using TSDC relaxometry method $[11,29]$. Similar results could be obtained using NMR cryoporometry applied to hydrated cells $[11,29,30]$. 

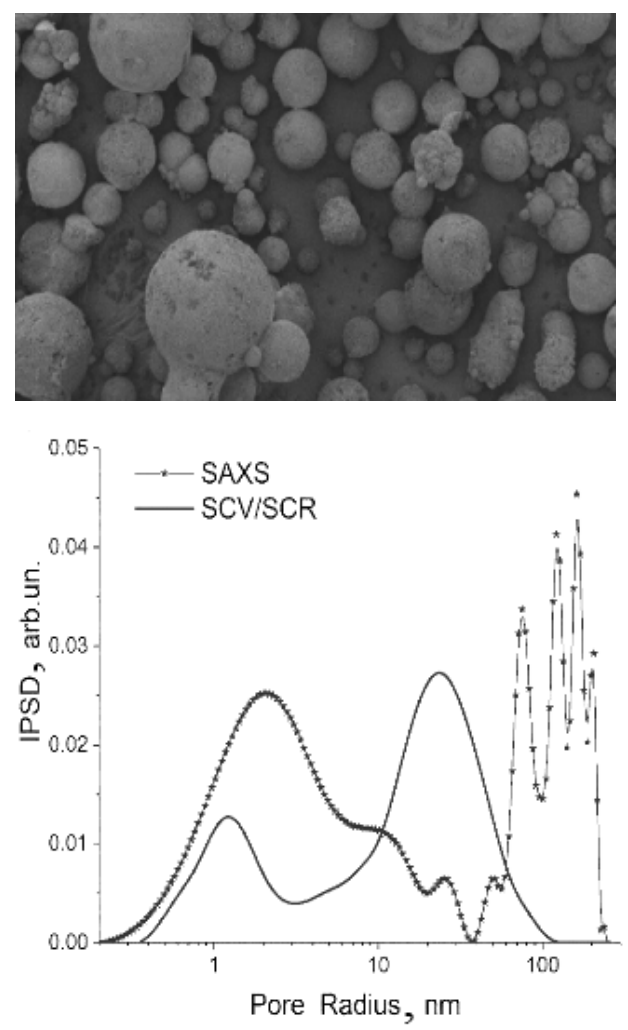

$a$

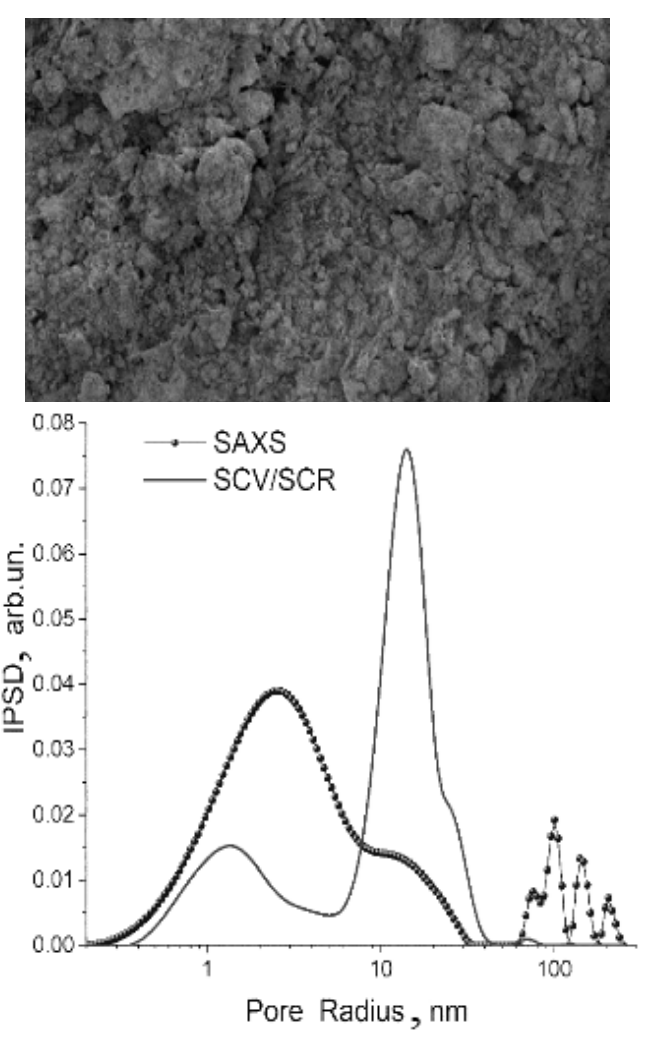

$b$

Fig. 19. Incremental pore size distributions calculated from nitrogen adsorption-desorption isotherms and SAXS data for lignin-containing polydivinylbenzene microspheres at $\mathrm{S}_{\mathrm{BET}}=(a) 409 \mathrm{~m}^{2} / \mathrm{g}$ and $(b) 542 \mathrm{~m}^{2} / \mathrm{g}$ [46]

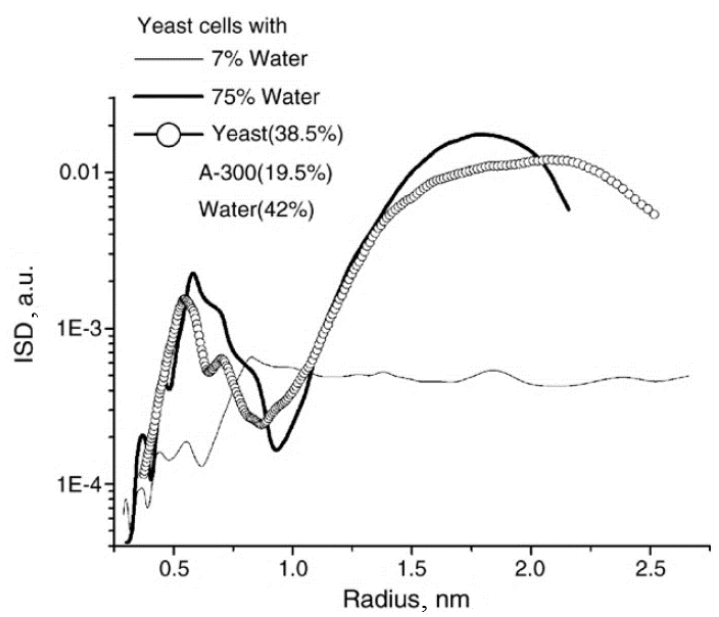

Fig. 20. Size distribution of water clusters (which can be considered as intra-cell voids filled by water) in yeast cells calculated on the basis of the TSDC data [29]

\section{CONCLUSIONS}

Several ways were described for analysis of the morphological and textural characteristics of different materials. These approaches: (i) adsorption-desorption of low-molecular weight probe compounds $\left(\mathrm{N}_{2}, \mathrm{CO}_{2}, \mathrm{Ar}, \mathrm{C}_{6} \mathrm{H}_{6}, \mathrm{H}_{2} \mathrm{O}\right.$, etc. $)$ in the gaseous (vapor) phase with increasingdecreasing pressure that gives the adsorptiondesorption isotherms analyzed in detail using specific software; (ii) adsorption of lowmolecular weight compounds from liquid solutions with increasing concentration of a 
solute; (iii) small angle X-ray scattering (SAXS) or small angle neutron scattering (SANS); (iv) quantitative analysis of images recorded using microscopic methods such as HRTEM, SEM, CLSM, etc.; (v) thermoporometry based on DSC or TG measurements with decreasing-increasing temperature; (vi) cryoporometry based on NMR spectroscopy measurements vs. temperature; and (vii) relaxometry based on NMR spectroscopy and thermally stimulated depolarization current measurements vs. temperature give a comprehensive picture on the morphology and texture of various adsorbents. There are several reasons of the use of these different methods in parallel. For example, a material, which in a native state is strongly hydrated, can change the texture upon drying. Various adsorbates can penetrate in different pores or differently fill pores of different sizes that also depends on the chemical structure of the wall of different pores (e.g. walls of nanopores and meso/macropores of AC can have different chemical compositions) and the nature of probes. There are accessible and inaccessible pores (closed or too narrow for used adsorbates), but SAXS can give complete information on all pores in contrast to the adsorption methods. This information could be useful for analysis of possible changes upon treatment (activation) of the materials to improve their characteristics.

\title{
Різні методи для опису морфологічних та текстурних характеристик різних матеріалів
}

\section{В.М. Гунько}

Інститут хімії поверхні ім. О.О. Чуйка Національної академії наук України вул. Генерала Наумова, 17, Київ, 03164, Україна, vlad_gunko@ukr.net

\begin{abstract}
Метою роботи було порівняння різних методів опису текстурних характеристик різних матеріалів. Кілька шляхів може бути обрано для детального опису морфології та текстури різних матеріалів: (i) адсорбиія-десорбиія низькомолекулярних сполук $\left(\mathrm{N}_{2}, \mathrm{CO}_{2}, \mathrm{Ar}, \mathrm{C}_{6} \mathrm{H}_{6}, \mathrm{H}_{2} \mathrm{O}\right.$ тощо) в газовій (паровій) фазі 3 підвищенням-зменшенням тиску, що дає адс-дес ізотерми, які аналізують з використанням специфічних програм; (ii) адсорбиія низькомолекулярних сполук з рідкого середовища при підвищенні концентращіі;; (iii) малокутове розсіяння рентгенівських променів (SAXS) чи малокутове розсіяння нейтронів (SANS); (iv) кількісний аналіз мікрозображень ТЕМ, СЕМ, КЛСМ тощо; (v) термопорометрія на основі ДСК та ТГ вимірювань при зниженні-підвищенні температури; (vi) кріопорометрія на основі ЯМР спектроскопії при зміні температури; (vii) релаксометрія на основі ЯМР та термостимульованої деполяризаиії. $\epsilon$ кілька причин для паралельного використання вказаних методів. Наприклад, матеріал, який в нативному стані $\epsilon$ сильно гідратованим, може суттєво змінити текстуру при дегідратації; тому треба вивчати його характеристики в обох станах. Різні адсорбати можуть проникати у пори різних розмірів, що треба враховувати при аналізі різних даних. $С$ доступні та недоступні (закриті чи дуже вузькі), проте SAXS дає повну інформацію про усі пори на відміну від адсорбиійних методів. Таким чином, чим більша кількість різних методів використовується, тим більш повна морфологічна та текстурна характеризація забезпечується, щчо було показано в даній роботі.
\end{abstract}

Ключові слова: текстурні характеристики, адсорбиія, кріопорометрія, релаксометрія, термопорометрія, SAXS, FTIR 


\title{
Разные методы для описания морфологических и текстурных характеристик различных материалов
}

\author{
В.М. Гунько \\ Институт химии поверхности им. А.А. Чуйка Национальной академии наук Украиньь \\ ул. Генерала Наумова, 17, Киев,03164, Украина, vlad_gunko@ukr.net
}

\begin{abstract}
Целью данной работы было сравнение разных методов для описания текстурных характеристик разных материалов. Несколько путей могут быть избраны для описания морфологии и текстуры различных материалов: (i) адсорбиия-десорбичи низкомолекулярных соединений ( $\mathrm{N}_{2}, \mathrm{CO}_{2}, \mathrm{Ar}, \mathrm{C}_{6} \mathrm{H}_{6}, \mathrm{H}_{2} \mathrm{O}$ и т.д.) в газовой (паровой) фазе с повышением-понижением давления, что дает адс-дес изотермы, которые анализируют с использованием специифических программ; (ii) адсорбция низкомолекулярных соединений из жидкой среды при повышении концентрации; (іiі) малоугловое рассеяние рентгеновских лучей (SАХS) или малоугловое рассеяние нейтронов (SANS) (iv) количественный анализ микроизображений TEM, CEM, КЛСМ и тому подобное; (v) термопорометрия на основе ДСП и ТГ измерений при снижении-повышении температуры; (vi) криопорометрия на основе ЯМР спектроскопии при изменении температуры; (vii) релаксометрия на основе ЯМР и термостимулированной деполяризации. Есть несколько причин для параллельного использования различных методов. Например, материал, который в нативном состоянии является сильно гидратированным, может существенно изменить текстуру при дегидратации, поэтому надо исследовать материал в обоих состояниях. Различные адсорбаты могут проникать в поры различных размеров, что нужно учитывать при анализе различных данных. Есть доступные и недоступные (закрытые или очень узкие), однако SAXS дает полную информацию о всех порах в отличие от адсорбционных методов. Таким образом, чем большее количество разных методов используется, тем более полная морфологическая $и$ текстурная характеризация обеспечивается, что и было показано в данной работе.
\end{abstract}

Ключевые слова: текстурные характеристики, адсорбиия, криопорометрия, релаксометрия, термопорометрия, SAXS, FTIR

\section{REFERENCES}

1. Adamson A.W., Gast A.P. Physical Chemistry of Surface. Sixth edition. (New York: Wiley, 1997).

2. Gregg S.J., Sing K.S.W. Adsorption, Surface Area and Porosity. (London: Academic Press, 1982).

3. Brumberger H. (Ed.) Small Angle X-ray Scattering. (New York: Gordon \& Breach, 1965).

4. $\quad$ Iler R.K. The Chemistry of Silica. (Chichester: Wiley, 1979).

5. Bergna H.E. (Ed.) Colloidal Silica: Fundamentals and Applications. (Boca Raton: Taylor \& Francis LLC, 2005).

6. Legrand A.P. (Ed.) The Surface Properties of Silicas. (New York: Wiley, 1998).

7. Hastie J.W. (Ed.) Materials Chemistry at High Temperatures. V.1, Characterization, V.2, Processing and Performance. (Clifton, NJ: Humana Press, 1990).

8. Ullmann's Encyclopedia of Industrial Chemistry. (Weinheim: Wiley-VCH, 2008).

9. Kimmich R. NMR Tomography, Diffusometry, Relaxometry. (Heidelberg: Springer, 1997).

10. Mitchell J., Webber J.B.W., Strange J.H. Nuclear magnetic resonance cryoporometry. Phys. Rep. 2008. $461(1): 1$.

11. Gun'ko V.M., Turov V.V. Nuclear Magnetic Resonance Studies of Interfacial Phenomena. (Boca Raton: CRC Press, 2013).

12. Gun'ko V.M. Composite materials: textural characteristics. Appl. Surf. Sci. 2014. 307: 444.

13. Gun'ko V.M., Mikhalovsky S.V. Evaluation of slitlike porosity of carbon adsorbents. Carbon. 2004. 42(4): 843.

14. Gun'ko V.M., Meikle S.T., Kozynchenko O.P., Tennison S.R., Ehrburger-Dolle F., Morfin I., Mikhalovsky S.V. Comparative characterization of carbon and polymer adsorbents by SAXS and nitrogen adsorption methods. J. Phys. Chem. C. 2011. 115(21): 10727.

15. Gun'ko V.M., Savina I.N., Mikhalovsky S.V. Cryogels: Morphological, structural and adsorption characterization. Adv. Colloid Interface Sci. 2013. 187-188: 1.

16. Gun'ko V.M., Goncharuk O.V., Goworek J. Evaporation of polar and nonpolar liquids from silica gels and fumed silica. Colloids Surf. A. 2015. 474: 52.

17. Gun'ko V.M. Interfacial phenomena: effects of confined space and structure of adsorbents on the behavior of polar and nonpolar adsorbates at low temperatures. Current Physical Chemistry. 2015. 5(2): 137. 
18. Gun'ko V.M., Pakhlov E.M., Skubiszewska-Zięba J., Blitz J.P. Infrared spectroscopy as a tool for textural and structural characterization of individual and complex fumed oxides. Vib. Spectrosc. 2017. 88: 56.

19. Pujari P.K., Sen D., Amarendra G., Abhaya S., Pandey A.K., Dutta D., Mazumder S. Study of pore structure in grafted polymer membranes using slow positron beam and small-angle X-ray scattering techniques. Nucl. Instrum. Methods Phys. Res., Sect. B. 2007. 254(2): 278.

20. Dieudonné Ph., Hafidi A.A., Delord P., Phalippou J. Transformation of nanostructure of silica gels during drying. J. Non-Cryst. Solids. 2000. 262(1-3): 155.

21. Fairén-Jiménez D., Carrasco-Marín F., Djurado D., Bley F., Ehrburger-Dolle F., Moreno-Castilla C. Surface area and microporosity of carbon aerogels from gas adsorption and small- and wide-angle X-ray scattering measurements. J. Phys. Chem. B. 2006. 110(17): 8681.

22. Petrov O.V., Furó I. NMR cryoporometry: Principles, applications and potential. Prog. Nucl. Magn. Reson. Spectrosc. 2009. 54(2): 97.

23. Aksnes D.W., Forl K., Kimtys L. Pore size distribution in mesoporous materials as studied by ${ }^{1} \mathrm{H}$ NMR. Phys. Chem. Chem. Phys. 2001. 3: 3203.

24. Muniz W.B., Ramos F.M., de Campos Velho H.F. Entropy- and Tikhonov-based regularization techniques applied to the backwards heat equation. Comput. Math. Appl. 2000. 40(8-9): 1071.

25. Provencher S.W. A constrained regularization method for inverting data represented by linear algebraic or integral equations. Comput. Phys. Commun. 1982. 27(3): 213.

26. Gun'ko V.M., Turov V.V., Turov A.V., Zarko V.I., Gerda V.I., Yanishpolskii V.V., Berezovska I.S., Tertykh V.A. Behaviour of pure water and water mixture with benzene or chloroform adsorbed onto ordered mesoporous silicas. Centr. Eur. J. Chem. 2007. 5(2): 420.

27. Gun'ko V.M., Krupska T.V., Andriyko L.S., KlymenkoN.Yu., Siora I.V., Novikova O.A., Marynin A.I., Ukrainets A.I., Charmas B., Shekhunova S.B., Turov V.V. Bonding of doxorubicin to nanosilica and human serum albumin in various media. J. Colloid Interface Sci. 2018. 513: 809.

28. Turov V.V., Gun'ko V.M., Pakhlov E.M., Krupska T.V., Tsapko M.D., Charmas B., Kartel M.T. Influence of hydrophobic nanosilica and hydrophobic medium on water bound in hydrophilic components of complex systems. Colloids Surf. A. 2018. 552: 39.

29. Gun'ko V.M., Zarko V.I., Goncharuk E.V., Andriyko L.S., Turov V.V., Nychiporuk Y.M., Leboda R., Skubiszewska-Zięba J., Gabchak A.L., Osovskii V.D., Ptushinskii Y.G., Yurchenko G.R., Mishchuk O.A., Gorbik P.P., Pissis P., Blitz J.P. TSDC spectroscopy of relaxational and interfacial phenomena. Adv. Colloid Interface Sci. 2007. 131(1-2): 1.

30. Gun'ko V.M., Turov V.V., Zarko V.I., Goncharuk E.V., Turova A.A. Regularities in the behaviour of water confined in adsorbents and bioobjects studied by ${ }^{1} \mathrm{H}$ NMR spectroscopy and TSDC methods at low temperatures. Colloids Surf. A. 2009. 336: 147.

31. Hay J.N., Laity P.R. Observations of water migration during thermoporometry studies of cellulose films. Polymer. 2000. 41(16): 6171.

32. Landry M.R. Thermoporometry by differential scanning calorimetry: experimental considerations and applications. Thermochim. Acta. 2005. 433(1-2): 27.

33. Weber J., Bergström L. Mesoporous hydrogels: revealing reversible porosity by cryoporometry, X-ray scattering, and gas adsorption. Langmuir. 2010. 26(12): 10158.

34. Rohman G., Lauprêtre F., Boileau S., Guérin P., Grande D. Poly(D,L-lactide)/poly(methyl methacrylate) interpenetrating polymer networks: synthesis, characterization, and use as precursors to porous polymeric materials. Polymer. 2007. 48(24): 7017.

35. Turov V.V., Gun'ko V.M., Zarko V.I., Goncharuk O.V., Krupska T.V., Turov A.V., Leboda R., SkubiszewskaZięba J. Interfacial behavior of $n$-decane bound to weakly hydrated silica gel and nanosilica over a broad temperature range. Langmuir. 2013. 29(13): 4303.

36. Goworek J., Stefaniak W., Zgrajka W. Measuring porosity of polymeric adsorbents by temperature programmed desorption of liquids. Mater. Chem. Phys. 1999. 59(2): 149.

37. Goworek J., Stefaniak W., Prudaczuk M. The influence of polarity of liquids on the parameters characterizing the porosity of silica gels estimated by thermogravimetric analysis. Thermochim. Acta. 2001. 379(1): 117.

38. Gun'ko V.M., Kozynchenko O.P., Tennison S.R., Leboda R., Skubiszewska-Zięba J., Mikhalovsky S.V. Comparative study of nanopores in activated carbons by HRTEM and adsorption methods. Carbon. 2012. 50(9): 3146.

39. Gun'ko V.M., Turov V.V., Kozynchenko O.P., Nikolaev V.G., Tennison S.R., Meikle S.T., Snezhkova E.A., Sidorenko A.S., Ehrburger-Dolle F., Morfin I., Klymchuk D.O., Mikhalovsky S.V. Activation and structural and adsorption features of activated carbons with highly developed micro-, meso- and macroporosity. Adsorption. 2011. 17(3): 453. 
40. Zheng Y., Gun'ko V.M., Howell C.A., Sandeman S.R., Phillips G.J., Kozynchenko O.P., Tennison S.R., Ivanov A.E., Mikhalovsky S.V. Composites with macroporous poly(vinyl alcohol) cryogels with attached activated carbon microparticles with controlled accessibility of a surface. ACS Appl. Mater. Interfaces. 2012. 4(11): 5936.

41. Sandeman S.R., Gun'ko V.M., Bakalinska O.M., Howell C.A., Zheng Y., Kartel M.T., Phillips G.J., Mikhalovsky S.V. Adsorption of anionic and cationic dyes by activated carbons, PVA hydrogels and PVA/AC composite. J. Colloid Interface Sci. 2011. 358(2): 582.

42. Turov V.V., Turova A.A., Goncharuk E.V., Gun'ko V.M. Adsorption of methane with the presence of water on oxide, polymer and carbon adsorbents studied using ${ }^{1} \mathrm{H}$ NMR spectroscopy at low temperatures. Appl. Surf. Sci. 2008. 255(5): 3310.

43. Tóth A., Voitko K.V., Bakalinska O.N., Prykhod'ko G.P., Bertóti I., Martínez-Alonso A., Tascón J.M.D., Gun'ko V.M., László K. Morphology and adsorption activity of chemically modified MWCNT probed by nitrogen, n-propane and water vapor. Carbon. 2012. 50(2): 577.

44. Gun'ko V.M., Turov V.V., Pakhlov E.M., Krupska T.V., Charmas B. Effect of water content on the characteristics of hydro-compacted nanosilica. Appl. Surf. Sci. 2018. 459: 171.

45. Gun'ko V.M., Leboda R., Skubiszewska-Zięba J., Gawdzik B., Charmas B. Structural characteristics of porous polymers treated by freezing with water or acetone. Appl. Surf. Sci. 2005. 252(3): 612.

46. Goliszek M., Podkościelna B., Fila K., Sevastyanova O., Aminzadeh S., Gun'ko V.M. Synthesis and structure characterization of polymeric nanoporous microspheres with lignin. Cellulose. 2018. 25(10): 5843. 